\title{
1 Mineral Changes in Cement-Sandstone Matrices Induced by Biocementation
}

2 C. Verba $^{1^{*}}$, A.R. Thurber ${ }^{2}$, Y. Alleau ${ }^{2}$, D. Koley ${ }^{3}$, F. Colwell ${ }^{2}$, and M.E. Torres ${ }^{2}$.

3
${ }^{1}$ National Energy Technology Laboratory, U.S. Department of Energy, OR 97321, USA

${ }^{2}$ College of Earth, Ocean, and Atmospheric Sciences, Oregon State University, OR 97330, USA

${ }^{3}$ College of Science, Oregon State University, OR 97330, USA

*Corresponding author: circe.verba@ netl.doe.gov

\section{Abstract}

Prevention of wellbore $\mathrm{CO}_{2}$ leakage is a critical component of any successful carbon capture, utilization, and storage program. Sporosarcina pasteurii is a bacterium that has demonstrated the potential ability to seal a compromised wellbore through the enzymatic precipitation of $\mathrm{CaCO}_{3}$. Here we investigate the growth of $S$. pasteurii in a synthetic brine that mimics the Illinois Basin and on Mt. Simon sandstone encased in Class H Portland cement under high pressure and supercritical $\mathrm{CO}_{2}\left(\mathrm{P}_{\mathrm{CO} 2}\right)$ conditions. The bacterium grew optimum at $30^{\circ} \mathrm{C}$ compared to $40^{\circ} \mathrm{C}$ under ambient and high pressure (10 MPa) conditions; and growth was comparable in experiments at high $\mathrm{P}_{\mathrm{CO} 2}$. Sporosarcina pasteurii actively induced the biomineralization of $\mathrm{CaCO}_{3}$ polymorphs and $\mathrm{MgCa}\left(\mathrm{CO}_{3}\right)_{2}$ in both ambient and high pressure conditions as observed in electron microscopy. In contrast, abiotic (non-biological) samples exposed to $\mathrm{CO}_{2}$ resulted in the formation of surficial vaterite and calcite. The ability of $S$. pasteurii to grow under subsurface conditions may be a promising mechanism to enhance wellbore integrity.

Keywords: Biofilm, biomineralization, bioprecipitation, carbon sequestration, Sporosarcina pasteurii, supercritical $\mathrm{CO}_{2}$ 


\section{INTRODUCTION}

Carbon sequestration pilot programs are being conducted to evaluate the injection of carbon dioxide $\left(\mathrm{CO}_{2}\right)$ into deep geological formations to mitigate the rise in atmospheric $\mathrm{CO}_{2}$ concentrations. During carbon sequestration, it is essential to maintain wellbore integrity to prevent the injected $\mathrm{CO}_{2}$ from leaking either into adjacent formations or being released back into the atmosphere (e.g. McGrail et al., 2006). Several pathways exist in which $\mathrm{CO}_{2}$ leakage could lead to groundwater or surficial aquifer contamination, but the probability of $\mathrm{CO}_{2}$ leakage is greater at the cement-host lithologies interface, around the annulus, and at the cement plug (e.g. Duguid et al., 2011; Gasda, et al., 2013).

Class G or H Portland cement paste is used in oil and gas wells and is composed of unhydrated calcium silicates, calcium aluminoferrites, magnesium oxide phases, and hydrated phases such as calcium hydroxide $\left(\mathrm{Ca}(\mathrm{OH})_{2}\right)$ or semi-amorphous calcium silicate hydrate (known as C-S-H in cement nomenclature) (Taylor, 1997). Carbon dioxide injected during carbon capture and storage (CCUS) exists as a supercritical fluid at depths greater than $800 \mathrm{~m}$ where critical pressures $(>7.38 \mathrm{MPa})$, and temperatures $\left(>31.1^{\circ} \mathrm{C}\right)$ exist. Several studies have documented alteration of hydration products in the cement paste in the presence of supercritical $\mathrm{CO}_{2}$ and $\mathrm{CO}_{2}$-saturated brine (e.g. Kutchko, 2007, 2008; Barlet-Gouédard et al., 2009; Fabbri et al., 2009). Furthermore, poor bonding or emplacement of cement combined with supercritical $\mathrm{CO}_{2}$ conditions may reduce the effectiveness of carbon capture. The reaction of $\mathrm{CO}_{2}$ with cement is provided below with Equations 1-5 (Kutchko, 2007). This is a two-step process where the

47 formation of carbonic acid results in the dissolution of $\mathrm{Ca}(\mathrm{OH})_{2}$, and subsequently the conversion of C-S-H into amorphous silica gel.

$$
\mathrm{CO}_{2(g)} \rightarrow \mathrm{CO}_{2(a q)}
$$

$$
\mathrm{CO}_{2}+\mathrm{H}_{2} \mathrm{O} \leftrightarrow \mathrm{H}_{2} \mathrm{CO}_{3} \leftrightarrow \mathrm{HCO}_{3}^{-}+\mathrm{H}^{+} \leftrightarrow 2 \mathrm{H}^{+}+\mathrm{CO}_{3}{ }^{2-}
$$

$$
\mathrm{Ca}(\mathrm{OH})_{2(s)} \rightarrow \mathrm{Ca}^{2+}{ }_{(a q)}+2 \mathrm{OH}_{(a q)}
$$

$$
\mathrm{Ca}^{2+}{ }_{(a q)}+\mathrm{HCO}_{3}^{-}{ }_{(a q)}+\mathrm{OH}_{(a q)} \rightarrow \mathrm{CaCO}_{3(s)}+\mathrm{H}_{2} \mathrm{O}
$$

$$
2 \mathrm{H}^{+}+\mathrm{CO}_{3}{ }^{2-}+\mathrm{C}-\mathrm{S}-\mathrm{H}_{(s)} \rightarrow \mathrm{CaCO}_{3(s)}+\mathrm{H}_{2} \mathrm{O}_{(a q)}+a m-\mathrm{SiO}_{2(s)}
$$


Microbially induced mineralization is a potential mechanism to control fluid migration or seal wellbores via the bioprecipitation of calcium carbonate (Dejong et al., 2013; Phillips et al. 2013). The use of Sporosarcina pasteurii to improve oil recovery by modifying preferred flow paths in oil-bearing formations was proposed by Ferris and Stehmeier (1992) and most recently Phillips et al., (2013) reviewed the utilization of biomineralization to increase wellbore cement integrity. Sporosarcina pasteurii produces urease as a metabolic byproduct and in the presence of urea and $\mathrm{Ca}^{2+}$, deposition of calcium carbonate occurs (Fujita et al., 2008; Mitchell and Ferris, 2006, Mitchell et al. 2008, Colwell et al., 2005, Phillips et al. 2013; 2015). Exploitation of this reaction in engineered systems is useful to strengthen unconsolidated porous media (Van Passen, 2011) and reduce permeability of sandstone fractures (Phillips et al. 2015). Mitchell et al. (2013) found $S$. pasteurii to be metabolically active and capable of precipitating calcium carbonate in saline and porous synthetic media in the presence of supercritical $\mathrm{CO}_{2}$ at $7.5 \mathrm{MPa}$ and $32^{\circ} \mathrm{C}$. This work showed that bacterial ureolysis (hydrolysis of urea) led to increased $\mathrm{pH}$ (up to 9.1) and nucleation of calcite. The total amount of calcite precipitated was limited by mass transport of $\mathrm{Ca}^{2+}$ ions and urea.

Microbially produced urease catalyzes the hydrolysis of urea into carbonic acid and ammonia; carbonic acid and ammonia dissociate in water to form ammonia, hydroxide, and bicarbonate ions. Provided there is a calcium source, this reaction will lead to the subsequent precipitation of calcium carbonate as described in Equation 6 (Mitchell et al., 2013). For $S$. pasteurii to be used at the field scale to effectively seal wellbores, its growth and ability to produce urease needs to be evaluated at conditions that will be found in wellbore environments, specifically high temperature, salinity, and pressure.

Class $\mathrm{H}$ Portland cement is commonly used in wellbores making it amenable to the reaction above in the presence of calcium enriched brine. Well temperatures can exceed $40^{\circ} \mathrm{C}$ and pressure increases with depth. Phillips et al. (2015) demonstrated in laboratory experiments 81 that pressures $(4.5 \mathrm{MPa})$ in wells would not be detrimental to $S$. pasteurii's ability to seal cracks 82 in the cement. Further, moderate temperature $\left(32^{\circ} \mathrm{C}\right)$ and pressure $(7.5 \mathrm{MPa})$ did not preclude 83 this species from mediating the precipitation of $\mathrm{CaCO}_{3}($ Mitchell et al. 2013). However, much is 
84 left to be learned about the synergistic impacts of temperature, brine, and pressure on the growth 85 and ability of $S$. pasteurii to precipitate $\mathrm{CaCO}_{3}$ under the conditions where fractured sealing 86 would be most beneficial to supercritical $\mathrm{CO}_{2}$ storage. In both of the previously cited papers, the 87 medium used to test the efficacy of $S$. pasteurii was a nutrient rich solution that is unlike the 88 brine found in those aquifers most likely to be used for supercritical $\mathrm{CO}_{2}$ injection. We 89 investigate the mineralogical changes induced by S. pasteurii in cement bonded to Mt. Simon 90 sandstone immersed in high salinity brine at various temperature and pressure conditions, and in 91 the presence of supercritical $\mathrm{CO}_{2}$. Supporting experiments were conducted on bacteria growing 92 in a nutrient rich broth and brine, as well as precipitation on membrane filters and cement93 sandstone samples to test the limiting factors on the growth of S. pasteurii in subsurface 94 conditions. 


\section{EXPERIMENTAL METHODS}

\subsection{SAMPLE PREPARATION}

To simulate in situ (down hole pressure and temperature) conditions in the experiments, we used a sandstone sample cored from the Mt. Simon formation, prepared raw Class H Portland cement, and prepared a brine solution to match that of the fluids in a target $\mathrm{CO}_{2}$ injection site in the Mt. Simon formation. The brine was comprised of $\mathrm{NaCl}, \mathrm{CaCl}_{2}, \mathrm{MgCl}_{2}$, and trace salt species (Table 1; based on Hazen core data, Illinois State Geological Survey). All sample conditions are described in Table 2. The Mt. Simon sandstone is a coarse grained sandstone that overlies Precambrian granite and underlies fine-grained Eau Claire Formation (c.f., Bonneville et al., 2013). A core sample from the Mt. Simon Formation acquired 1198 meters below land surface (provided by J. Szecsody, Pacific Northwest National Laboratory) was sub-cored into $1.3 \mathrm{~cm}$ diameter cylinders.

The raw Class H Portland cement powder (Lafarge) contained 64.5 wt. \% tricalcium silicate $\left(\mathrm{Ca}_{3} \mathrm{SiO}_{5}\right), 11.77$ wt. \% dicalcium silicate $\left(\mathrm{Ca}_{2} \mathrm{SiO}_{4}\right), 13.24$ wt. \% calcium aluminoferrite $\left(\mathrm{Ca}_{4} \mathrm{AlFeO}_{5}\right), 2.94$ wt. $\% \mathrm{MgO}, 2.8$ wt. $\% \mathrm{SO}_{4}{ }^{2-}$, and 0.16 wt. \% total alkali content $\left(\mathrm{Na}_{2} \mathrm{O}\right)$. This cement has no tricalcium aluminate $\left(\mathrm{Ca}_{3} \mathrm{Al}_{2} \mathrm{O}_{6}\right)$. The cement powder contained $0.62 \%$ free lime $(\mathrm{CaO})$. The [water] loss on ignition (LOI) was computed to be 0.73 , a value that is within acceptable ASTM limits. The cement slurry was prepared using a water-rock (w/c) ratio of 0.38 composed of $500 \mathrm{~g}$ dry cement powder and $190 \mathrm{ml}$ of distilled water according to American Petroleum Institute (API) Recommended Practice RP10-B. The sandstone sub-cores were encased in a cement slurry, cured for 24 hours in a humidity controlled room, removed from the mold, and subsequently immersed in a $30^{\circ} \mathrm{C}$ Mt. Simon brine bath to cure for 28 days at 1) ambient pressure or 2) at $10 \mathrm{MPa}$ (hydraulic or $\mathrm{P}_{\mathrm{CO} 2}=10 \mathrm{MPa}$ ) to simulate the expected pressure at the target injection site. All cores were cured at the pressure that they would be subjected to during the respective experiments. After the curing period, the cement-sandstone cores were cut into $1.3 \mathrm{~cm}$ slices for detailed imaging and characterization at ambient and high pressures and at variable temperatures, as described below. 


\subsection{CULTURE GROWTH EXPERIMENTS AT AMBIENT CONDITIONS}

123 Sporosarcina pasteurii (strain 11859) used for all experiments was obtained from the 124 American Type Culture Collection (ATCC). We tested growth in 1) both a nutrient-rich broth, 2)

125 in calcium-enriched Mt. Simon brine, and 3) on cement-sandstone cores immersed in Mt. Simon

126 brine. An additional experiment quantified growth on membrane filters placed on top of an agar 127 made with the nutrient-rich broth. The ideal growth medium for this strain (referenced as 'ATCC 128 medium') is composed of $20.0 \mathrm{~g}$ yeast extract and $10.0 \mathrm{~g}$ ammonium sulfate in $1.0 \mathrm{~L} 0.13 \mathrm{M}$ Tris 129 Buffer ( $\mathrm{pH}$ 9.0). The Tris Buffer was autoclaved (sterilized) prior to adding the yeast extract and 130 ammonium sulfate, and then filter-sterilized using $0.2 \mu \mathrm{m}$ syringe filters. All glassware used 131 throughout the experiment was heat sterilized by autoclave. Early in the experiments, we 132 observed rapid and abiotic precipitation of $\mathrm{MgHPO}_{4}$ when an inoculum in ATCC medium was 133 added to the brine as a result of brine-medium interactions (see sections 3.1 and 4.1). To prevent 134 formation of $\mathrm{MgHPO}_{4}$ crystals in subsequent experiments, an aliquot $(0.5 \mathrm{ml}$ to $1.0 \mathrm{ml})$ of the 135 inoculum was centrifuged $(1,200 \mathrm{rpm}$ for 10 minutes) to pellet the bacteria and then the 136 supernatant medium was replaced with brine. The cell pellets were rinsed at least $3 \mathrm{x}$ with brine 137 to remove all traces of the ATCC medium prior to inoculating the brine solution. Sterilized Mt. 138 Simon brine was augmented with 1 or $10 \mathrm{~g}$ per liter of urea, as this substrate is needed for the 139 hydrolysis reaction to occur over a 7 day period.

140 Bacterial cells in sub-samples from each treatment (e.g., ambient and high pressure 141 conditions) were visualized by epifluroescent microscopy and enumerated by direct cell 142 counting. Aliquots from each treatment were preserved using formaldehyde (2\% final 143 concentration) and stored at $4^{\circ} \mathrm{C}$ until counting. Briefly, each preserved sample was filtered 144 through a black $25 \mathrm{~mm}$ diameter $0.2 \mu \mathrm{m}$ cyclopore (Whatman) membrane filter. A glass-fiber 145 backing filter $(\mathrm{GF} / \mathrm{F})$ was used beneath the membrane filter to produce an even distribution of 146 the bacteria on the membrane. The bacteria on the filter were stained using Sybr Gold nucleic 147 acid dye, visualized using an epifluroescent microscope, and enumerated by direct counting. At 148 least 10 frames and a total of 200 bacterial cells were counted per slide at 600x magnification. 149 The software ImagePro was used to enumerate the bacteria on each slide. Automated 150 enumeration was double-checked by direct visualization and counting. While growth curves are 
151 presented for ambient pressure, sequential sampling was not possible during high pressure 152 rocking autoclave experiments (see below in section 2.3).

Sporosarcina pasteurii was also grown on cyclopore membrane filters to investigate 154 morphological growth progression. For these experiments, ATCC media was inoculated with $S$. 155 pasteurii and grown for 48 hours at $30{ }^{\circ} \mathrm{C}$ to ensure that the bacterium was in the same growth 156 phase for each replicate. A $1 \mathrm{ml}$ aliquot of cell suspension was washed (as above) in brine to 157 remove phosphate in the media. Then $2.5 \mu \mathrm{L}$ of brine suspended bacteria were carefully drop158 casted on a membrane $(0.22 \mu \mathrm{m}$ pore diameter $)$ and placed on an agar petri dish with the ATCC 159 growth medium in the agar. The petridishes were incubated at $30^{\circ} \mathrm{C}$ for 72 hours. A $5 \mathrm{ml}$ brine 160 solution containing $1 \mathrm{~g} / \mathrm{L}$ urea was added to the petri dish for 60 seconds to precipitate calcium 161 carbonate and stabilize the biofilm before being replaced by brine with variable urea 162 concentrations. After incubation for $0.25,4,24$ and 96 hours the membranes were imaged by 163 scanning electron microscopy (SEM) and scanning electrochemical microscopy (SECM). For a 164 complete description of the SECM application, see Harris et al. (2016).

165 Bacterial biofilm formation and biomineralization on cement and sandstone was 166 investigated using cylinders of sandstone encased in cement that were inoculated with $S$. 167 pasteurii. Cement-sandstone samples prepared at $30{ }^{\circ} \mathrm{C}$ in Mt. Simon brine solution were placed 168 in $99 \%$ ethanol for 15 minutes to sterilize the outer surfaces. We did not autoclave these samples 169 to sterilize them as that would alter the chemical and physical structure of the cement. Cement170 sandstone samples were dried in autoclaved beakers prior to being immersed in fresh brine 171 containing either 1 or $10 \mathrm{~g} / \mathrm{L}$ urea. The immersed samples were incubated at $30{ }^{\circ} \mathrm{C}$ for 7 days. At 172 the end of the incubation period the samples were imaged (Canon T3i mounted to a Leica M80 173 stereoscope) and placed in a $2 \%$ formaldehyde solution to preserve the microbial community.

\subsection{ROCKING AUTOCLAVE EXPERIMENTS}

175 Cement-sandstone samples were cured at $30{ }^{\circ} \mathrm{C}$ or $40{ }^{\circ} \mathrm{C}$ and $10 \mathrm{MPa}$ for 28 days, 176 sterilized with ethanol, and dried in a $\mathrm{N}_{2}$ purged desiccator for 8 hours. As described above 177 (Section 2.2) an inoculum culture of S. pasteurii in the ATCC medium was subjected to repeated 178 centrifugation and brought back into suspension in sterile brine $(1 \mathrm{~mL}$, centrifuge, $15 \mathrm{~mL}$ of 179 brine with $10 \mathrm{~g} / \mathrm{L}$ urea respectively). An aliquot of the culture was removed and preserved with 
180 formaldehyde to obtain a time zero population count. A dual furnace ${ }^{\circledR}$ CoreTest System rocking 181 autoclave was used to conduct high pressure (hydraulic or $\mathrm{P}_{\mathrm{CO} 2}=10 \mathrm{MPa}$ ) and temperature (30 182 and $\left.40{ }^{\circ} \mathrm{C}\right)$ tests of inoculated and non-inoculated samples. The rocking system (45/180 degree 183 rotation) was used to promote rock-water interactions.

184 Control experiments were run without inoculation of S. pasteurii for abiotic comparisons. 185 For the biotic incubations, $14 \mathrm{ml}$ of $S$. pasteurii culture was added to a Ti-flexible cell that 186 contained the cement-sandstone sample. The remaining volume of the Ti-cell was filled with Mt. 187 Simon brine solution for a 1:3:1 rock-water-gas ratio. The system was pressurized hydraulically, 188 checked for leaks, and then heated to the desired temperature. After 16 hours of operation, a 20 $\mathrm{ml}$ sample of fluid was taken from each Ti-cell, $20 \mathrm{ml}$ (volume). $\mathrm{CO}_{2}$ gas was fed into the

190 system through a supercritical $\mathrm{CO}_{2}$ booster pump to attain pressure of $10 \mathrm{MPa}$, and set to rock 191 once the pressure was stable. After two weeks, autoclaves were stopped, a solution sample was 192 taken under high pressure and temperature conditions using a Hamilton style glass syringe and 193 the $\mathrm{pH}$ was measured immediately. This style of syringe as it allowed us to extract samples under 194 pressure to minimize degassing prior to $\mathrm{pH}$ measurement. The autoclaves were then 195 depressurized over a 2 hour period. At this point an aliquot was collected and preserved with 196 formaldehyde for determination of bacterial abundance. Cement-sandstone samples were 197 removed from the Ti-cells and placed in a $-20{ }^{\circ} \mathrm{C}$ freezer to prevent cement hydration and 198 microbial activity prior to further analysis. No other aqueous chemistry was conducted due to the 199 high total dissolved solid content of the brine and the dissolved ammonium analysis was 200 inconclusive (Table 1).

\subsection{SAMPLE CHARACTERIZATION}

Sample analysis and characterization of phase changes in the Class $\mathrm{H}$ cement and Mt.

203 Simon sandstone before and after incubation experiments were completed using a petrographic 204 optical microscope, a field emission (FE) FEI Inspect F scanning electron microscope (SEM), 205 and a JEOL 7000F FE-SEM. Uncoated samples were examined with an accelerating voltage of $206 \quad 5-12 \mathrm{keV}$ and a spot size 4.5 (dimensionless) to obtain high-resolution secondary electrons (SE) 207 images. By combining backscatter electron (BSE) imaging and energy dispersive spectroscopy 208 (EDS) we were able to acquire semi-quantitative elemental concentrations using the INCA 
209 software (Oxford). Specific samples were analyzed further with a wavelength-dispersive 210 spectrometer (WDS) with standard errors and correction matrices for cement.

211 Growth of $S$. pasteurii on thin films was imaged by applying a $\sim 50 \mu 1$ drop of fixative 212 (2.5\% glutaraldehyde, $1 \%$ paraformaldehyde in $0.1 \mathrm{M}$ sodium cacodylate buffer) to the frozen 213 filter. After 4 hours at room temperature, the film was rinsed for 10 minutes in sodium 214 cacodylate buffer. Samples were prepared for SEM by a serial dehydration of acetone 215 (concentrations: 10\%, 30\%, 50\%, 70\%, 90\%, and 100\%) for 15 minutes and subsequently critical 216 point dried. Dried filters were sputter coated with gold/palladium (60/40) for SEM. Images and 217 electron dispersive spectrometry were acquired using a FEI Quanta 600F environmental SEM 218 with an EDAX X-ray EDS detector at $8 \mathrm{kV}$ with a spot size of 5.

219 Cementitious and mineral phases were characterized using X-ray diffraction (XRD). 220 Diffraction patterns were collected using a Rigaku Ultima III with a $40 \mathrm{KV} / 40 \mathrm{~mA} \mathrm{Cu} \mathrm{K} \alpha$ source 221 and a step speed of $1^{\circ} \theta /$ minute over a scan angle $2 \theta$ of $5^{\circ}$ to $90^{\circ}$. The qualitative analysis of 222 XRD data was performed using Jade v9.1.4 Plus software and the International Center for 223 Diffraction Data (ICDD) pattern databases (ICDD, 2008). 


\section{RESULTS}

225

226

227

228

229

230

231

232

233

234

235

236

237

238

239

240

241

242

243

244

245

246

247

248

249

250

251

\subsection{CULTURE GROWTH AT AMBIENT PRESSURE AND 30/40 ${ }^{\circ} \mathrm{C}$}

In the first experimental trial, it was difficult to accurately calculate the growth rate of $S$. pasteurii because of the rapid precipitation of magnesium hydrogen-phosphate (200-500 $\mu \mathrm{m}$ in diameter) within minutes. This was the result of phosphate present in the media (Figure 1). The media was re-evaluated, and reproducible growth rates in an ideal growth medium were determined (see Section 4.1 for more details on applications).

The synergistic impact of both temperature and brine solution were tested by ability of $S$. pasteurii growth at multiple temperatures in nutrient broth alone or in a brine solution. Sporosarcina pasteurii grew best in the nutrient broth (ATCC medium) at $30{ }^{\circ} \mathrm{C}$ and were stable at $40{ }^{\circ} \mathrm{C}$, whereas the cell numbers attained in the Mt. Simon brine (with $1 \mathrm{~g} / \mathrm{L}$ or $10 \mathrm{~g} / \mathrm{L}$ urea added) were lower and more temperature dependent (Figure 2). The density of the bacteria increased from $7.7 \times 10^{4}\left( \pm 2.8 \times 10^{4}\right.$ Standard Error; SE $=$ Standard Deviation $\left./ \sqrt{ } \mathrm{n}\right)$ cells per $\mathrm{ml}$ to $1.1 \times 10^{6}\left( \pm 6.5 \times 10^{4} \mathrm{SE}\right)$ cells per $\mathrm{ml}$ within 24 hours of inoculation in the nutrient broth at $30{ }^{\circ} \mathrm{C}$. This growth rate slowed after 7 days with a low among replicate variance $3.79 \times 10^{6}$ per $\mathrm{ml}( \pm 9.4$ $\mathrm{x} 10^{4} \mathrm{SE}$ ). At $40{ }^{\circ} \mathrm{C}$ the bacteria had a slower initial growth with higher variance among replicates; starting with the same inoculation density of $7.7 \times 10^{4}\left( \pm 2.8 \times 10^{4} \mathrm{SE}\right)$ cells per ml the population reached a density of $1.7 \times 10^{5}\left( \pm 2.4 \times 10^{4} \mathrm{SE}\right)$ cells per $\mathrm{ml}$ after 24 hours. At this warmer temperature, the maximum density after 7 days was $1.4 \times 10^{6}\left( \pm 1.0 \times 10^{5} \mathrm{SE}\right)$ cells per ml, or $\sim 38 \%$ of the final density at $30^{\circ} \mathrm{C}$.

In all scenarios containing the Mt. Simon brine, the number of cells declined from its initial inoculation concentration within the first 6 hours before stabilizing at a lower concentration (Figure 2). At $30{ }^{\circ} \mathrm{C}$, this stabilization ranged between $3.0 \times 10^{4}$ and $4.0 \times 10^{4}$ cells per $\mathrm{ml}$ with a much higher among replicate variance for both the 1 and $10 \mathrm{~g} / \mathrm{L}$ urea treatments. For example, at 7 days, the standard error was $45 \%$ of the mean population density for $1 \mathrm{~g} / \mathrm{L}$ urea and $30^{\circ} \mathrm{C}$ treatment; this is also indicated by the much large error bars (Figure 2). At $40{ }^{\circ} \mathrm{C}$, there was again a rapid decrease after the inoculation with counts ranging $2.6-3.7 \times 10^{4}$ cells per $\mathrm{ml}$ in both brine and urea treatments. In the $40{ }^{\circ} \mathrm{C}$ treatment, the population did not recover from the 
252 initial reduction in concentration post-inoculation; the $1 \mathrm{~g}$ urea/L treatment was reduced to 1.0 $253 \times 10^{4}\left( \pm 0.9 \times 10^{3} \mathrm{SE}\right)$ cells per $\mathrm{ml}$ after 7 days and in the $10 \mathrm{~g}$ urea/L no cells were visible even 254 with repeated and extensive attempts to quantify them across all replicates at this time point. 255 Our conservative minimum estimated detection limit was 130 cells per ml.

256 Total cell count numbers decreased from the initial inoculation concentration in brine 257 (including urea) over 7 days, SEM images and analyses of cyclopore membrane filters inoculated 258 with $S$. pasteurii immersed in the brine solution with low $(1 \mathrm{~g} / \mathrm{L})$ and high $(10 \mathrm{~g} / \mathrm{L})$ at $30{ }^{\circ} \mathrm{C}$ 259 illustrates the rapid precipitation and progression of bioprecipitated matrix over 96 hours (Figure 260 3). SECM analyses demonstrated that calcium carbonate layer formed quickly after inoculation 261 ( $<0.25$ hours) and the carbonate morphology becomes more pronounced after 96 hours with a 262 nodular appearance (Figure 3 enlarged area with distinct crystals). Direct SECM measurements 263 on the same samples, show a rapid increase in $\mathrm{pH}$, from 6.9 up to 9.2 within the first 10 minutes 264 of incubation, approximately $\sim 200 \mu \mathrm{m}$ above the biofilm. The average thickness of the measured 265 biofilm was $95 \pm 10 \mu \mathrm{m}$ with topography ranging 20-87 $\mu \mathrm{m}$ as measured with a SECM 266 (concurrent with this study, Harris et al., 2016).

\subsection{CHARACTERIZATION OF CEMENT-SANDSTONE SUBSTRATES}

The Mt. Simon sandstone is a mature, coarsely graded arenite, containing 99\% quartz $\left(\mathrm{SiO}_{2}\right.$-rich) bands with banded oxidized iron hydroxide and Fe-Ti-oxides (Figure 4). Based on light microscopy and SEM, the typical grain size is $\sim 401 \pm 26 \mu \mathrm{m}$ with $10 \%$ porosity. The pore space is filled with micaceous minerals, specifically muscovite $\left.\left(\mathrm{KAl}_{2}\left(\mathrm{AlSi}_{3} \mathrm{O}_{10}\right)(\mathrm{OH})_{2}\right)\right)$. Other 273 include hematite $\left(\mathrm{Fe}_{2} \mathrm{O}_{3}\right)$, ilmenite $\left(\mathrm{FeTiO}_{3}\right), \mathrm{CuCO}_{3}$, and trace $(<1 \%)$ nichromite $274\left((\mathrm{Ni}, \mathrm{Co}, \mathrm{Fe})(\mathrm{Cr}, \mathrm{Fe}, \mathrm{Al})_{2} \mathrm{O}_{4}\right)$ or ferrianchromite $\left(\mathrm{Fe}^{2+}\left(\mathrm{Cr}, \mathrm{Fe}^{3+}\right)_{2} \mathrm{O}_{4}\right)$ less than $<5 \mu \mathrm{m}$ across.

At the time of observation, the cement paste surrounding the sandstone contained 276 approximately $25 \%$ unhydrated calcium silicates, calcium aluminate ferrites, and magnesium 277 oxide phases that had not reacted with water to form $\mathrm{Ca}(\mathrm{OH})_{2}$ or semi-gel like C-S-H (Figure 4). 278 The cement appears to have bonded fairly well (no apparent surface defects) to the sandstone; 279 electron backscatter analysis revealed higher concentration of C-S-H at the interface. There were 280 minor concentrations of dendritic hydrotalcite $\left(\left(\mathrm{Mg}_{6} \mathrm{Al}_{2}\left(\mathrm{CO}_{3}\right)(\mathrm{OH})_{16} \cdot 4\left(\mathrm{H}_{2} \mathrm{O}\right)\right)\right.$ on $\mathrm{MgO}$ grains. 


\subsection{GROWTH ON CEMENT-SANDSTONE SAMPLES}

In both brine treatments $(1$ and $10 \mathrm{~g} / \mathrm{L}$ urea $)$ at $30{ }^{\circ} \mathrm{C}$ at atmospheric pressure, a biofilm formed on the cement-sandstone samples that was white in appearance due to the deposition of calcium carbonate (Figure 5). $\mathrm{CaCO}_{3}$ deposition seemed to occur more rapidly at higher concentrations of urea as observed by the formation of the biofilm crust on the cement that extended into the sandstone surface (Figure 5). At $1 \mathrm{~g} / \mathrm{L}$ urea the colonies were smaller and more dispersed with $\sim 17 \%$ surface area coverage, whereas at $10 \mathrm{~g} / \mathrm{L}$ urea, the total area coverage was $\sim 61 \%$ with larger, denser colonies determine by the ratio of detected pixels to total pixels in ImagePro. The biofilm and crust were measured to be $20-75 \mu \mathrm{m}$ thick with distinct crystal morphologies in SEM. Figure 6a shows that the top surface in contact with the bulk fluid had $\mathrm{CaCO}_{3}$ polymorphs (aragonite and calcite), trace dolomite $\left(\mathrm{MgCa}\left(\mathrm{CO}_{3}\right)_{2}\right)$, trace gypsum $\left(\mathrm{CaSO}_{4} * 2 \mathrm{H}_{2} \mathrm{O}\right)$, and halite $(\mathrm{NaCl})$; all phases were confirmed by XRD. S. pasteurii cells, either encased or adjacent to $\mathrm{CaCO}_{3}$ polymorphs, were observed on the underside of the crust. SEMBSE images showed that the rod-shaped bacteria which range in length between 6-7 $\mu \mathrm{m}$ and 3.1$3.3 \mu \mathrm{m}$ in diameter appeared to be covered in a biotic-induced calcified crust as seen in Figure 6 under atmospheric pressure in $10 \mathrm{~g} / \mathrm{L}$ urea.

\subsection{GROWTH AT HIGH PRESSURE}

The S. pasteurii populations survived and grew at $30{ }^{\circ} \mathrm{C}$ and high pressure $\left(\mathrm{P}_{\mathrm{CO} 2}=10\right.$ $\mathrm{MPa}$ ) as indicated by their population increasing 7.8 fold over the experiment. Over this same time, bulk fluid $\mathrm{pH}$ changed to 12 from 6.7. Injection of the supercritical $\mathrm{CO}_{2}$ along with the rocking motion at 45 degrees had no observable negative impact on S. pasteurii populations (Figure 7). Furthermore, the bacterial density in the presence of $\mathrm{CO}_{2}$ was comparable to the population (final density/initial density) at ambient pressure in the nutrient broth (Figure 7). SEM images show that the biofilm nucleated on the cement with calcium carbonate crust had an average thickness of $\leq 20 \mu \mathrm{m}$ at both temperatures as measured via SEM analysis (Figure 8). The cells in these films were $<5 \mu \mathrm{m}$ in length and $2 \mu \mathrm{m}$ in diameter and had not been entirely encased by $\mathrm{CaCO}_{3}$. However, at $40{ }^{\circ} \mathrm{C}$, the bacterial cell numbers were lower than observed at 30 ${ }^{\circ} \mathrm{C}$ under supercritical $\mathrm{CO}_{2}$ conditions; the density only increased by $60 \%\left(1.8 \times 10^{3}\right.$ to $3.0 \times 10^{3}$ cells per ml) at $40{ }^{\circ} \mathrm{C}$ over the same period of time that population at $30{ }^{\circ} \mathrm{C}$ (863 to $4.0 \times 10^{4}$ cells 
310 per ml; Figure 7). In this experiment, the $\mathrm{pH}$ of the solution increased to 11 in the $40{ }^{\circ} \mathrm{C}$ 311 treatment.

312 Other factors such as rocking and incubation under hydraulic pressure had different 313 results on population growth and stability. For example, at $30{ }^{\circ} \mathrm{C}$, under supercritical $\mathrm{CO}_{2}$

314 conditions with 180 degrees of rocking, the population growth rate was much slower $(1.8 \mathrm{x}$ 315 increase in cell density over the duration of the experiment, or from $4.4 \times 10^{3}$ to $8.4 \times 10^{3}$ cells per $316 \mathrm{ml}$ ) than the sample that experienced 45 degree rocking (46x increase in cell density or 863 to $3174.0 \times 10^{4}$ cells per ml). At $40{ }^{\circ} \mathrm{C}$, the sample was broken up and formed a slurry due to the 180 318 degrees rocking motion, making it difficult to accurately enumerate bacterial cells in the sample 319 as the fragments occluded the view of the microscope. In addition, the high pressure hydraulic 320 treatments $\left(\right.$ no $\mathrm{CO}_{2}$ ) at $30^{\circ} \mathrm{C}$ had a final cell density that increased 7.8 fold (from $6.9 \times 10^{3}$ to 5.4 $321 \times 10^{4}$ cells per $\mathrm{ml}$ ) whereas the 45 degree rocking $30{ }^{\circ} \mathrm{C}$ with $\mathrm{P}_{\mathrm{CO} 2}$ conditions had the 322 aforementioned 46 fold increase in cell density. However, this may have been an artifact of the 323 especially low inoculation density in the $30^{\circ} \mathrm{C}$ treatment with $\mathrm{P}_{\mathrm{CO} 2}$. In the absence of $\mathrm{CO}_{2}$ at 40 $324{ }^{\circ} \mathrm{C}$, the cell density increase was nearly double (from $7.9 \times 10^{3}$ to $3.3 \times 10^{4}$ cells per ml) of that 325 observed in the $\mathrm{P}_{\mathrm{CO} 2}$ samples at $40{ }^{\circ} \mathrm{C}$ (from $1.8 \times 10^{3}$ to $3.0 \times 10^{4}$ cells per ml; Figure 7). Of note, 326 each of these treatments had final densities of $\sim 10^{4}$ cells per ml. The abiotic sample, which did 327 not contain bacteria pre- or post-experiment, was omitted from the bacterial comparison as there 328 were no bacteria observed.

\subsection{ABIOTIC AND BIOTIC CARBONATION}

Carbonates form naturally on cement in the presence of $\mathrm{CO}_{2}$. However, there are key differences between the abiotic cement subjected to $\mathrm{CO}_{2}\left(\mathrm{CO}_{2}\right.$-saturated fluid and supercritical $\mathrm{CO}_{2}$ ) and cement samples inoculated with $S$. pasteurii (Figures 9 and 10). The abiotic carbonated cement was composed primarily of polycrystalline vaterite $(1-2 \mu \mathrm{m})$ and well distributed rhombohedral calcite $(\sim 2 \mu \mathrm{m})$ that replaced the cementitious phases $\mathrm{Ca}(\mathrm{OH})_{2}$ and C-S-H. At both ambient and $\mathrm{P}_{\mathrm{CO} 2}=10 \mathrm{MPa}$, samples inoculated with $S$. pasteurii displayed bio-induced acicular and orthorhombic aragonite $(3-5 \mu \mathrm{m})$, rhombohedron calcite, and polycrystalline vaterite $(<1 \mu \mathrm{m})$. Petrographic analysis and electron microscopy show that the biofilm and subsequent biomineralization initiated in cement and extends onto the sandstone surface. 


\section{DISCUSSION}

\subsection{BIOGENIC PRECIPITATION: AMBIENT PRESSURE}

The rapid precipitation of $\mathrm{MgHPO}_{4}$ demonstrates the importance of understanding 342 complex brine chemistry, specifically brines containing phosphate. Furthermore, it highlights the

343 need to understand the components of culture media for application in laboratory experiments 344 and field applications. In this case, if a large inoculum of $S$. pasteurii was injected down 345 wellbore in the ideal growth medium, upon reaching the in situ brine an abiotic precipitate would 346 likely block the well rather than distribute the bacteria throughout the area targeted for repair by 347 the bacteria. Once phosphate was eliminated, the high concentration of calcium in the Mt. Simon 348 brine and from the cement resulted in calcium carbonate biomineralization in a more desired, 349 controlled reaction. We did not compare the growth of S. pasteurii in our "ideal" growth medium 350 to that used in other studies (e.g. Phillips et al. 2013); it is important to recognize that abiotic 351 precipitation of $\mathrm{MgHPO}_{4}$ should be considered when choosing the correct medium to use when 352 introducing S. pasteurii to a well. Based on the findings of Tobler et al (2012) it is possible to 353 avoid the use of media and subsequent phosphate precipitation by injecting cell lysate.

SEM-EDS, SEM-WDS, and XRD identification of the carbonate species demonstrated that $S$. pasteurii enabled biotic mineralization at $30{ }^{\circ} \mathrm{C}$ in brine containing urea. Specifically rhombohedral calcite, orthorhombic (hexagonal) and acicular aragonite, gypsum, and dolomite precipitated on the cement-sandstone surface (Figures 6 and 10). Sporosarcina pasteurii appears to have taken advantage of the cement for initial nucleation sites using calcium from $\mathrm{Ca}(\mathrm{OH})_{2}$ and $\mathrm{C}-\mathrm{S}-\mathrm{H}$ and inducing a higher concentration $(\sim 17 \%$ versus $\sim 61 \%$ surface area coverage at 1 and $10 \mathrm{~g} / \mathrm{L}$ urea respectively) of $\mathrm{CaCO}_{3}$ as seen in Fig. 5. Another example of microbiallyinduced mineral precipitation is the presence of a $\mathrm{Mg}$-carbonate, chemical similar to dolomite as identified by SEM-EDS found protruding from the cement pore space only in samples inoculated with S. pasteurii under ambient pressure (Fig. 6). SEM images support that microbes could be associated with the dolomite precipitation and could be indicative that the microorganisms used magnesium-enriched brine. The mechanism of the dolomite precipitation warrants further examination. Furthermore, a crustal layer of halite $(\mathrm{NaCl})$ was also present; however, we could 
not confirm if $\mathrm{NaCl}$ was produced as a result of metabolic activity, depressurization, or sample 368 preparation.

Based on our results, the efficacy of using $S$. pasteurii to seal wellbores appears to be limited by temperature and is less sensitive to urea concentrations. At $40{ }^{\circ} \mathrm{C}$ in the Mt. Simon brine, there was strong evidence that the population had a lower stable population density, at low urea concentrations, or was not viable at the higher urea concentrations. It is unclear why the concentration of urea impacted the growth of the species. We conclude that the species can live

374 at $40{ }^{\circ} \mathrm{C}$ for short durations, but the increased variance in population growth rates was indicative 375 of a population under stress.

Cells encased in $\mathrm{CaCO}_{3}$ are one potential mechanism that would lead to the observed discrepancy in population density in high urea samples and unable accurately count them. Microbially-induced carbonate precipitation leading to bacterial encapsulation has been suggested by Cuthbert et al. (2012) and verified by SECM. If encapsulation was the reason we saw reduced growth in the high urea and brine treatments, then we would expect to see some cells present throughout the experimentation. This was not seen in the $40{ }^{\circ} \mathrm{C}$, brine and high urea treatment and instead, even with an exhaustive search across all replicates, we detected no cells.

Bacteria encapsulated in a non-transparent shell (e.g. carbonate) are difficult to enumerate using standard light microscopy methods. While optical density may have been an alternative approach to the nucleic acid stain we employed, both of these approaches can be heavily influenced by mineral precipitation and cellular density. While the nucleic acid stain used does not only stain viable cells, it will not stain lysed cells making it useful as a proxy for cells that are intact. Future approaches could quantify cellular concentration using lipid or gene abundance techniques, however these approaches also have a difficult time separating intact vs. non-intact cells. Our enumeration approach has limitations, but are consistent across all 391 experimental treatments.

SEM images taken at various intervals $(0.25,4,24$, and 96 hours) on a membrane filter 393 inoculated with $S$. pasteurii in brine media illustrated precipitation of carbonate with time (Fig. 394 3). In addition, SECM measurements that as the local pH increased from 6.9 to 9.2 (within 10 395 minutes), indicating an extremely rapid ureolysis leading to deposition of calcite. These results 
are consistent with previous publications documenting a $\mathrm{pH}$ increase and calcite precipitation in

397 cultures of $S$. pasteurii (which was limited by mass transport of $\mathrm{Ca}^{2+}$ and urea) seen in Mitchell 398 et al. (2013). Our results add to the previous findings in that we document a bio-encasing effect 399 of the cultures, limiting further growth and biomineralization (e.g. Mitchell et al., 2013; Cuthbert 400 et al., 2012). Such time-point observations are key to the design of field tests, and suggest that 401 inoculation of test boreholes be done in short time steps rather than expecting long-term activity 402 for a given large pulse of inoculants. Such an approach was taken by Phillips et al. (2013) who 403 found a significant decrease in permeability in a sandstone core following the sequential addition 404 of urea after inoculation by S. pasteurii. Similar approaches need to be further tested at both 405 high pressure (e.g. Phillips et al. 2013), high pressure and temperature (Mitchell et al. 2013), and 406 in a brine solution (this study). As a result this species continues to hold promise for sealing 407 wellbores in shallow (not too warm) $\mathrm{CO}_{2}$ abatement sites, as well as the other diversity of 408 bioengineering roles that urease hydrolyzing bacteria may perform (reviewed in Phillips et al. 409 2015).

\subsection{BIOGENIC PRECIPITATION: HIGH PRESSURE AND TEMPERATURE}

Neither the increased pressure expected at wellbore depths nor the injection of 412 supercritical $\mathrm{CO}_{2}$ negatively impacted biomineralization induced by $S$. pasteurii, further 413 supporting that this species could act as a component of a mitigation strategy for leaky wellbores 414 targeted for carbon sequestration. During 2 weeks in a rocking autoclave at $30{ }^{\circ} \mathrm{C}$ and $\mathrm{P}_{\mathrm{CO} 2}=10$ $415 \mathrm{MPa}$, the microbial colonies formed an organic-rich biofilm as identified by SEM-EDS that led 416 to the formation of a globular $\mathrm{CaCO}_{3}$ crust (Figures 8-10). As observed in the ambient pressure 417 tests, colonization appeared to preferentially occur on the cement surface and extend across the 418 interface to the sandstone. The presence of $S$. pasteurii initiated the deposition of several phases 419 of $\mathrm{CaCO}_{3}$ : aragonite, calcite, and vaterite. There are several notable differences of the 420 biomineralization between ambient and high pressure. The first is the size of the twinning 421 aragonite crystals; at higher pressure, the twinned aragonite crystals are significantly smaller 422 (20 $\pm 8 \mu \mathrm{m}$ as compared to $90 \pm 33 \mu \mathrm{m}$ clusters). Secondly, the microbial colonies are partially 423 encased in secondary minerals. It was difficult to determine if the microbial colonies filled and 424 "healed" fractures at $\mathrm{P}_{\mathrm{CO} 2}$. 
It is important to note that under pressure with supercritical $\mathrm{CO}_{2}, S$. pasteurii was able to at least increase in density and lead to the precipitation of $\mathrm{CaCO}_{3}$, which is indicative of it 427 producing the urease enzymes. As the morphotype is distinct between biologically and non428 biologically mediated precipitates, it is plausible that living populations led to this observed 429 effect. This is comparative to ureolytic activity under anoxic conditions in which the 430 precipitation is based on the presence of enzymes within the system (Tobler et al., 2011; 431 Cuthbert et al., 2012). While other studies have found that the introduction of supercritical $\mathrm{CO}_{2}$ 432 under pressure can lead to a sterilization effect on certain taxa (e.g. Mitchell et al. 2008), we 433 observed inhibition of growth at increased temperature and pressure and that S. pasteurii was 434 able to survive under these conditions.

The population growth increased 46-fold over the duration of the experiment under $\mathrm{P}_{\mathrm{CO} 2}=$ 437 ideal growth medium at $30{ }^{\circ} \mathrm{C}$ (Figure 7). Petrographically, there is less biogenic precipitation 438 at $30{ }^{\circ} \mathrm{C}$ and $\mathrm{P}_{\mathrm{CO} 2}$, but cell data demonstrates that $S$. pasteurii appeared to be stable during $\mathrm{CO}_{2}$ 439 injection. Sporosarcina pasteurii appears to be limited by temperature as the population growth 440 of $S$. pasteurii was reduced 28 times at $40{ }^{\circ} \mathrm{C}$ compared to $30{ }^{\circ} \mathrm{C}$ at high $\mathrm{P}_{\mathrm{CO} 2}$ conditions. 441 However, at $40{ }^{\circ} \mathrm{C}\left(\mathrm{P}_{\mathrm{CO} 2}\right)$ the final population density was 1.6 times its initial concentration as 442 such the population was still able to grow. As seen in previous studies (Mitchell et al., 2013), this 443 study showed that the injection of $S$. pasteurii into shallow wellbore depths and at lower 444 temperatures $\left(<40{ }^{\circ} \mathrm{C}\right)$ could help to improve compromised wellbore cements; it may be possible 445 to seal fractures in a few days in wellbores where temperature is $>40{ }^{\circ} \mathrm{C}$. It is important to note 446 that many of sites for potential supercritical $\mathrm{CO}_{2}$ injection are at a minimum $40{ }^{\circ} \mathrm{C}$, and thus this 447 study is an important step forward in testing the efficacy of using S. pasteurii to seal wellbores in 448 such regions. Modeling future high pressure and temperature off the work of Phillips et al. 449 (2013) and Mitchell et al. (2013), with a strategy of sequential injection may likely lead to the 450 most effective approach to utilizing S. pasteurii for sealing wellbores.

\subsection{COMPARISON BETWEEN ABIOTIC AND BIOTIC CARBONATION}

S. pasteurii appeared to play an important role in bioprecipitation of aragonite and dolomite; S. pasteurii had an impact on the $\mathrm{pH}$ of the bulk solution where the biogenic $\mathrm{pH}$ was 
$454>11$ compared to the abiotic $\mathrm{pH}$ of 9. Petrographic examination of the biotic surfaces found 455 defined crystallization on the cement surface attributed to the presence of a biofilm. The biofilm 456 enhanced the formation of calcium carbonate as also seen by Cunningham et al. $(2009 ; 2011)$ 457 and Mitchell et al. (2013); the extent of the bio-induced mineralization was not evident in abiotic 458 samples (Figures 9 and 10). It is feasible, that as the cement continued to hydrate, the cement 459 pore solution increased in localized calcium to increase alkalinity and enhance carbonate 460 deposition. The crystal structure of the calcium carbonate in the biotic treatments compared to 461 that of the abiotic treatments varied considerably. The precipitation of vaterite, a metastable 462 calcium carbonate, is more dominant than calcite in samples exposed to only supercritical $\mathrm{CO}_{2}$, 463 while the presence of the $S$. pasteurii resulted in a more stable crystalline form of aragonite and 464 calcite. In agreement with our results, Abo-El-Enein et al. (2013) also found rhombohedral 465 calcium carbonate depositions by $S$. pasteurii exposed to calcium chloride. However, the 466 duration of $\mathrm{CO}_{2}$ injection was limited to 2 weeks; other studies have indicated calcite as typically 467 dominant in cement carbonation with lower concentrations of vaterite and longer test durations 468 (e.g. Verba et al., 2014; Kutchko, 2007). Future research is required to understand if the 469 chemical reaction is impacting the crystal lattice or if there is preferred orientation in the 470 presence of $S$. pasteurii. 


\section{CONCLUSIONS}

472

473

474

475

476

477

Our investigation of $S$. pasteurii growth in a synthetic brine that mimics the Illinois Basin and on Mt. Simon sandstone encased in Class H Portland cement, led to the following conclusions:

- Phosphate in media prompted rapid crystallization of $\mathrm{MgHPO}_{4}$. This is an important consideration when designing a suitable $S$. pasteurii culture in laboratory bench experiments and scaling up to field applications.

- At atmospheric pressures, S. pasteurii were stable in high chloride brine solutions, but performed best at temperatures of $30{ }^{\circ} \mathrm{C}$. The populations appeared to have reduced growth at $\geq 40{ }^{\circ} \mathrm{C}$, but were stable for up to 4 days and thus could facilitate the rapid sealing of wellbore cement at temperatures found in certain wellbore regions.

- S. pasteurii is actively modifying the deposition of $\mathrm{CaCO}_{3}$ on carbonate through its ureolytic activity at high pressure in brine environments. Biomineralization resulted in well crystallized $\mathrm{CaCO}_{3}$ polymorphs, notably aragonite, and $\mathrm{MgCa}\left(\mathrm{CO}_{3}\right)_{2}$ as analyzed in SEM-EDS and XRD.

- At $30{ }^{\circ} \mathrm{C}$ under $\mathrm{P}_{\mathrm{CO} 2}=10 \mathrm{MPa}$, S. pasteurii promoted additional $\mathrm{CaCO}_{3}$ precipitation compared to abiotic samples. This environmental resilience is encouraging as $S$. pasteurii may be better adapted to the supercritical $\mathrm{CO}_{2}$ conditions subject to respective temperatures.

- It is feasible that biogenic carbonation could improve wellbore integrity in carbon sequestration settings and could repair surface defects of the cement. Further research needs to be completed to understand if biomineralization can "heal" fractures and to document the optimal conditions for field implementation. 


\section{Disclaimer}

500 This report was prepared as an account of work sponsored by an agency of the United 501 States Government. Neither the United States Government nor any agency thereof, nor any of 502 their employees, makes any warranty, express or implied, or assumes any legal liability or 503 responsibility for the accuracy, completeness, or usefulness of any information, apparatus, 504 product, or process disclosed, or represents that its use would not infringe privately owned rights. 505 Reference therein to any specific commercial product, process, or service by trade name, 506 trademark, manufacturer, or otherwise does not necessarily constitute or imply its endorsement, 507 recommendation, or favoring by the United States Government or any agency thereof. The views 508 and opinions of authors expressed therein do not necessarily state or reflect those of the United 509 States Government or any agency thereof.

\section{Acknowledgments}

511 This work was completed as part of National Energy Technology Laboratory (NETL) 512 research for the Department of Energy's Pacific Coast Carbon Storage Initiative. The authors 513 wish to acknowledge Cindy Powell, (NETL Research and Innovation Center), William 514 Wierzbicki (AECOM URS), and Karl Schroeder for guidance and support. We also wish to 515 acknowledge Nicholas Huerta and Jeff Oberfoell in installation, testing, and assistance 516 throughout the experiments using the high pressure rocking autoclaves and Scott Montross for 517 technical review of this manuscript. The geological samples used in this study were acquired 518 through collaborations between Rick Colwell with Alain Bonneville and Jim Szecsody (Pacific 519 Northwest National Laboratory). 


\section{REFERENCES}

Abo-El-Enein, S.A. ,A.H. Ali, Fatma N. Talkhan, H.A. Abdel-Gawwad, Utilization of microbial induced calcite precipitation for sand consolidation and mortar crack remediation, HBRC Journal, 8 (3), pp 185-192, (2012).

Amemiya, S., Bard, A. J., Fan, F.-R. F., Mirkin, M. V and Unwin, P. R. Scanning electrochemical microscopy. Annu. Rev. Anal. Chem. (Palo Alto. Calif). 1, 95-131 (2008).

Bard, A. J., Li, X. \& Zhan, W. Chemically imaging living cells by scanning electrochemical microscopy. Biosens. Bioelectron. 22, pp. 461-72 (2006).

Bonneville A, Gilmore T, Sullivan C, Vermeul V, Kelley M, White S, Appriou D, Bjornstad B, Gerst J, Gupta N, Horner J, McNeil C, Moody M, Rike W, Spane F, Thorne P, Zeller E, Zhang F, Hoffmann J, Humphreys K. Evaluating the Suitability for $\mathrm{CO}_{2}$ Storage at the FutureGen 2.0 Site, Morgan County, Illinois, USA. Energy Procedia, 37, pp. 6125-6132. (2013).

Colwell FS, Smith RW, Ferris FG, et al. Microbially-mediated subsurface calcite precipitation for removal of hazardous divalent cations: Microbial activity, molecular biology, and modeling. Subsurface Contamination Remediation: Accomplishments of the Environmental Management Science Program, Berkey E \& Zachary T, eds., American Chemical Society, Washington, 904, pp. 117-137, (2005).

Cunningham, A.B., Gerlach, R., Spangler, L., Mitchell, A.C., 2009. Microbially enhanced geologic containment of sequestered supercritical $\mathrm{CO}_{2}$. Energy Procedia 1, 3245-3252.

Cunningham, A.B., Gerlach, R., Spangler, L., Mitchell, A.C., Parks, S., Phillips, A. Reducing the risk of wellbore leakage of $\mathrm{CO}_{2}$ using engineered biomineralization barriers. Energy Procedia 4, 5178-5185. (2011).

Cunningham, AB, Lauchnor, E, Eldring, J, Esposito, R, Mitchell, AC, Gerlach, R, Phillips, AJ. Ebigbo, A, Spangler, LH. Abandoned Well $\mathrm{CO}_{2}$ Leakage Mitigation Using Biologically Induced Mineralization: Current Progress and Future Directions. Greenhouse Gases: Science and Technology. 3, 1, 40-49. Special Issue: Selected papers from the 11th US annual conference on Carbon Capture, Utilization, and Sequestration. (2013). 
Cuthbert, M. O., Riley, M. S., Handley-Sidhu, S., Renshaw, J. C., Tobler, D. J., Phoenix,

548 V. R. \& Mackay, R. Controls on the rate of ureolysis and the morphology of carbonate 549 precipitated by S. Pasteurii biofilms and limits due to bacterial encapsulation. Ecological 550 Engineering, 41, pp. 32-40 (2012).

551 Dejong, DC., JT, Burbank M, Kavazanjian E, et al. Biogeochemical processes and 552 geotechnical applications: progress, opportunities and challenges. Geotechnique 63, pp. 287-301 553 (2013).

554 Demaret, L and H. J. Eberl. A finite difference scheme for a degenerated diffusion 555 equation arising in microbial ecology. Electronic Journal of Difference Equations, 15, pp. 77-95 556 (electronic), (2007).

557 Duvnjak, A. and H. J. Eberl. Time-discretization of a degenerate reaction-diffusion 558 equation arising in biofilm modeling. Electron. Trans. Numer. Anal., 23, pp. 15-37 (electronic), 559 (2006).

560 Duguid, A., Radonjic, M., and Scherer, G. W. (2011). Degradation of cement at the reservoir/cement interface from exposure to carbonated brine. International Journal of 562 Greenhouse Gas Control, 5(6), pp. 1413-1428. (2011).

Eberl H. J. and M. A. Efendiev. A transient density-dependent diffusion-reaction model 564 for the limitation of antibiotic penetration in biofilms. In Proceedings of the Fifth Mississippi 565 State Conference on Differential Equations and Computational Simulations (Mississippi State, 566 MS, 2001), Electron. J. Differ. Equ. Conf., 10. pp. 123-142 (electronic), (2003).

Ebigbo, A., R. Helmig, A. B. Cunningham, H. Class, and R. Gerlach. Modeling biofilm 569 growth in the presence of carbon dioxide and water in the subsurface. Advances in Water Resources, 33(7), pp. 762-781, (2010).

Ferris, TX., FG \& Stehmeier LG. Bacteriogenic mineral plugging. US Patent Office. Pat. No. 5,143,155. TX. (1992).

Fujita Y, Ferris FG, Lawson RD, Colwell FS \& Smith RW Calcium carbonate 573 precipitation by ureolytic subsurface bacteria. Geomicrobiol. J. 17, pp. 305-318. (2000). 
Fujita Y, Taylor JL, Gresham TL, et al. Stimulation of microbial urea hydrolysis in groundwater to enhance calcite precipitation. Environ. Sci. Tech. 42, pp. 3025-3032. (2008). Koley, D. Real-time monitoring of calcification process by Sporosarcina pasteurii biofilm. Analyst. DOI: 10.1039/C6AN00007J (2016).

Gasda, S., Celia, M., Wang, J., Duguid, A. Wellbore Permeability Estimates from https://www.isgs.illinois.edu/ilwater (2010).

Kutchko, B. G., Strazisar, B. R., Lowry, G. V., Dzombak, D. A., and Thaulow, N. Rate of $\mathrm{CO}_{2}$ attack on hydrated class $\mathrm{H}$ well cement under geologic sequestration conditions. Environ. Sci. Technol., 42(16), pp. 6237-6242. (2008).

Liu, X. et al. Real-time mapping of a hydrogen peroxide concentration profile across a polymicrobial bacterial biofilm using scanning electrochemical microscopy. Proc. Natl. Acad. Sci. U. S. A. 108, pp. 2668-73 (2011). carbon dioxide sequestration in flood basalts. J. Geophys. Res. 111. (2006). growth of calcium carbonate. Geomicrobiol. J. 23, 213-226. (2006).

Mitchell A. C., Ferris F. G. The influence of Bacillus pasteurii on the nucleation and 595 Fluids, 47, 318-325. (2008). enhanced carbon capture and storage by mineral-trapping and solubility-trapping. Environ. Sci. 598 Technol. 44, 5270-5276. (2010). 
saline aquifer with supercritical $\mathrm{CO}_{2}$. International Journal of Greenhouse Gas Control 15, pp. 602 86-96. (2013).

Parker D. F. van Loosdrecht M. C.M. Eberl, H. J. A new deterministic spatio-temporal 604 continuum model for biofilm development. Journal of Theoretical Medicine, 3(3), pp.161-175. 605 (2001). brine-rock interactions at elevated temperature and pressure: Implications for $\mathrm{CO}_{2}$ sequestration 617 in deep-saline aquifers. Fuel Processing Technology, 86, pp. 1581-1597. (2005). application of scanning electrochemical microscopy to bioanalytical systems. Biosens. Bioelectron. 23, 301-18. (2007).

Taylor, H. F. W. Cement Chemistry; Academic Press: New York (1997).

Tobler, D. J., Cuthbert, M. O., Greswell, R. B., Riley, M. S., Renshaw, J. C., HandleySidhu, S., and Phoenix, V. R.: Comparison of rates of ureolysis between Sporosarcina pasteurii and an indigenous groundwater community under conditions required to precipitate large volumes of calcite, Geochim. Cosmochim. Acta, 75, pp. 3290-3301, (2011).

Van Paassen LA Bio-mediated ground improvement: from laboratory experiment to pilot applications. ASCE Geotechnical Special Publication 211, pp. 4099-4108, (2011). 
652 Tables

653

654 Table 1: Top 5 salt species used to represent the Mt. Simon sandstone from the 655 Illinois Basin at the expected 1,220-1,250 m depth (Hazen well data, Illinois State 656 Geological Survey).

657

\begin{tabular}{|c|c|}
\hline $\begin{array}{c}\text { Simulated Mt. Simon } \\
\text { Sandstone Illinois Basin Brine }\end{array}$ & $\begin{array}{c}\text { Quantity, } \\
\text { g/L }\end{array}$ \\
\hline $\mathrm{NaHCO}_{3}$ & 0.84 \\
\hline $\mathrm{NaCl}$ & 59.36 \\
\hline $\mathrm{MgCl}_{2}$ & 5.71 \\
\hline $\mathrm{Na}_{2} \mathrm{SO}_{4}$ & 2.84 \\
\hline $\mathrm{CaCl}_{2}$ & 18.85 \\
\hline Total & 87.60 \\
\hline
\end{tabular}

658

659 
660 Table 2: Experimental conditions for culture growth experiments and rocking 661 autoclave experiments.

662

\begin{tabular}{|c|c|c|c|}
\hline \multicolumn{4}{|c|}{ Culture Growth Experiments } \\
\hline Media & Solution & Solution & Filter + Solution \\
\hline Solution & $\begin{array}{c}\text { Brine }^{2}+ \\
\text { Urea }\end{array}$ & Brine $^{2}+$ Urea & Brine $^{2}+$ Urea \\
\hline $\begin{array}{c}\text { Temperature } \\
\left({ }^{\circ} \mathbf{C}\right)\end{array}$ & 30 & 40 & 30 \\
\hline $\begin{array}{c}\text { Pressure } \\
\text { (MPa) }\end{array}$ & $\mathrm{ATS}^{3}$ & $\mathrm{ATS}^{3}$ & $\mathrm{ATS}^{3}$ \\
\hline Rocking & - & - & - \\
\hline Inoculum & S. pasteurii & S. pasteurii & S. pasteurii \\
\hline
\end{tabular}

Rocking Autoclave

Experiments

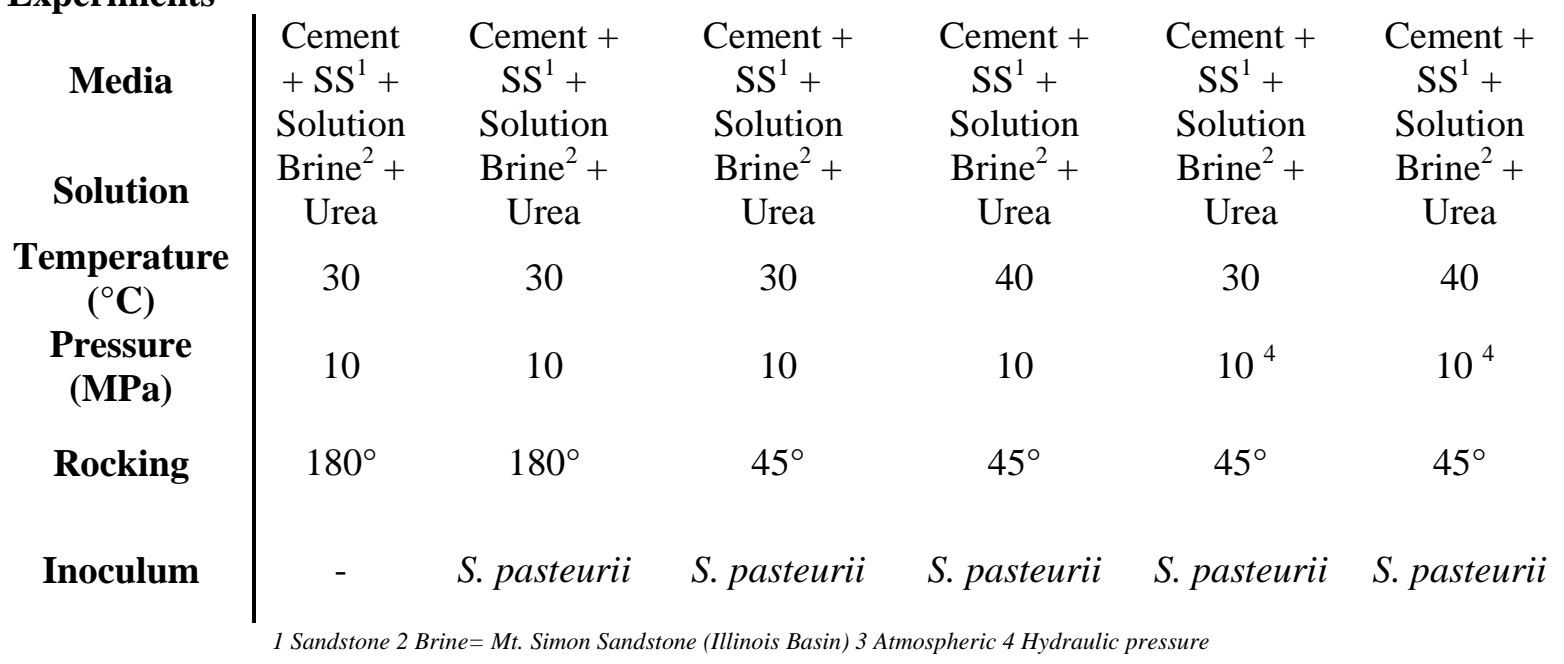




\section{Figures}

666
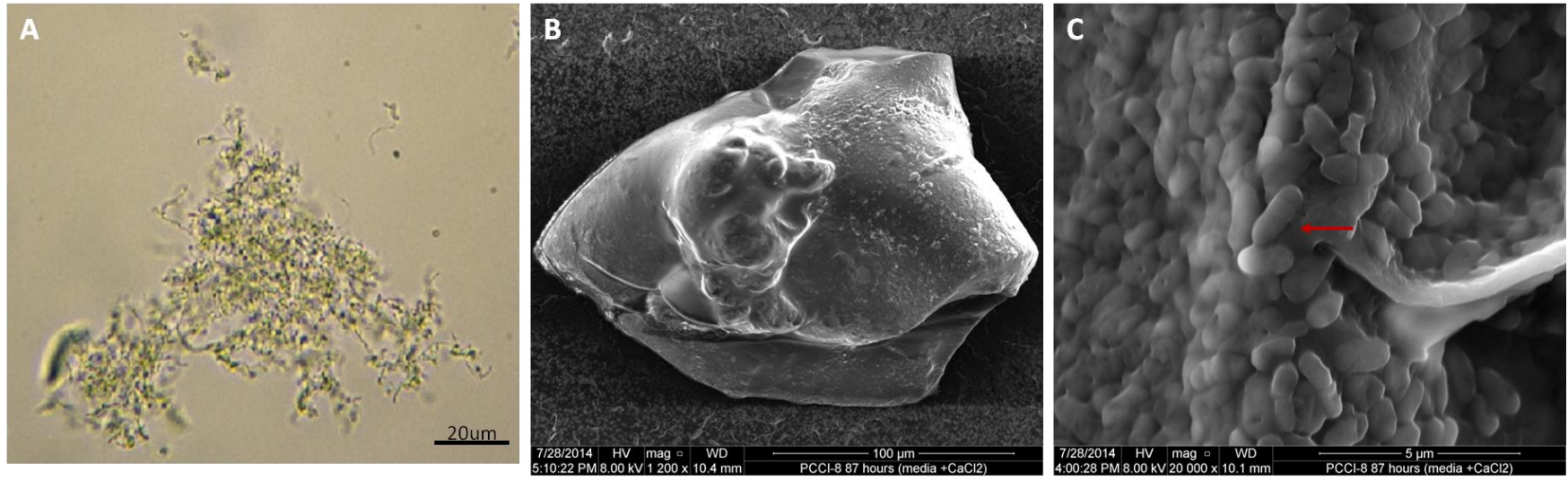

668 Figure 1 (A) Image of clumped S. pasteurii at 400x, after 24 hours incubation in a 669 media containing phosphate. (B) SEM-backscatter electron image showing the $670 \mathrm{MgHPO}_{4}$ crystals $(\mathbf{2 0 0}-\mathbf{5 0 0} \boldsymbol{\mu m}$ in diameter). The surface of these crystals are 671 covered by a biofilm layer. (C) Rod-shaped microbes (red arrow) (1.15-1.7 microns) 672 surrounding the $\mathrm{MgHPO}_{4}$ crystals. 

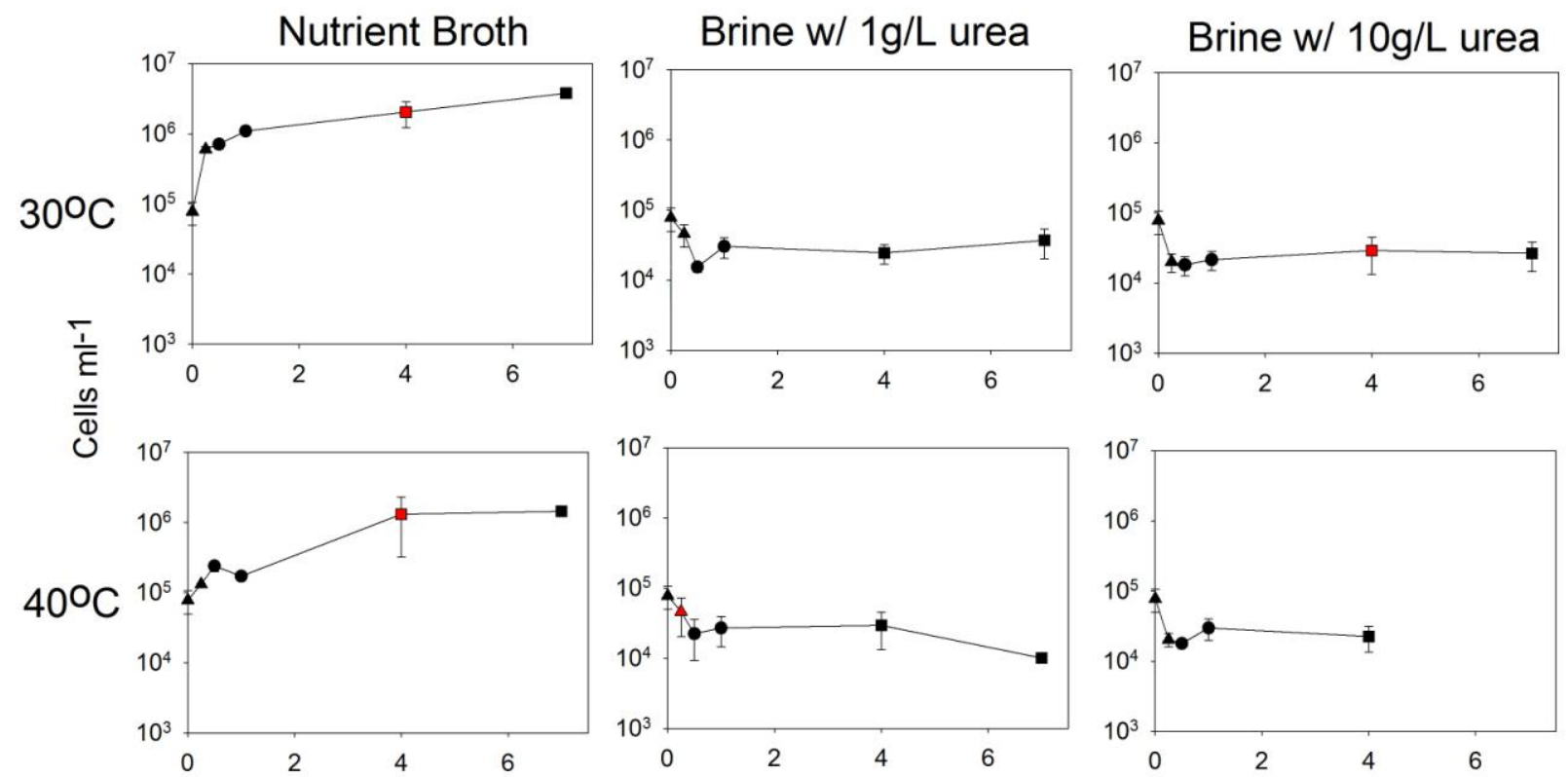

Days

678 Figure 2: S. pasteurii growth (log cell/ml up to 7 days) at different temperatures and growth media. Error bars are range of two replicates. $S$. pasteurii cell counts in the nutrient broth increased up to 7 days with low variability. However, inoculation in the brine displayed lower cell counts with temperature dependence. Population was below detection (estimated to be 130 bacteria per $\mathrm{ml}$ ) after 4 days at $40{ }^{\circ} \mathrm{C}$ at $10 \mathrm{~g} / \mathrm{L}$ in all three replicates. 

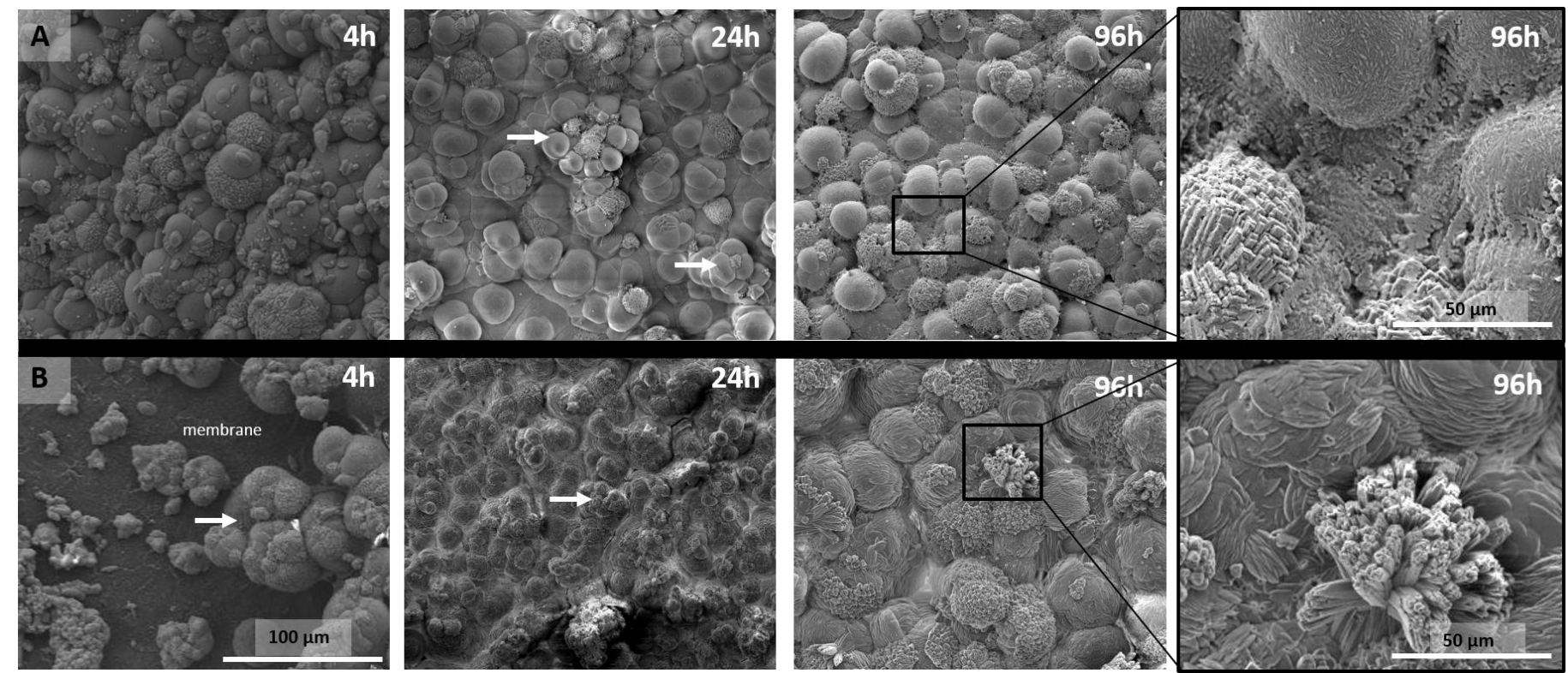

687 Figure 3: SEM micrograph of biofilm growth on cellulose membrane filters in brine 688 media with low and high urea at $30^{\circ} \mathrm{C}$ at ambient pressure up to 96 hours. The small 689 round topographical features (arrows) represent calcium carbonate precipitation on 690 the surface of the bacterial clusters. (A) High urea (10 g/L) (B) Low urea (1 g/L). 691 Scale bar for all images is $\mathbf{1 0 0} \boldsymbol{\mu m}$ except noted in the enlarged images as $\mathbf{5 0} \boldsymbol{\mu m}$.
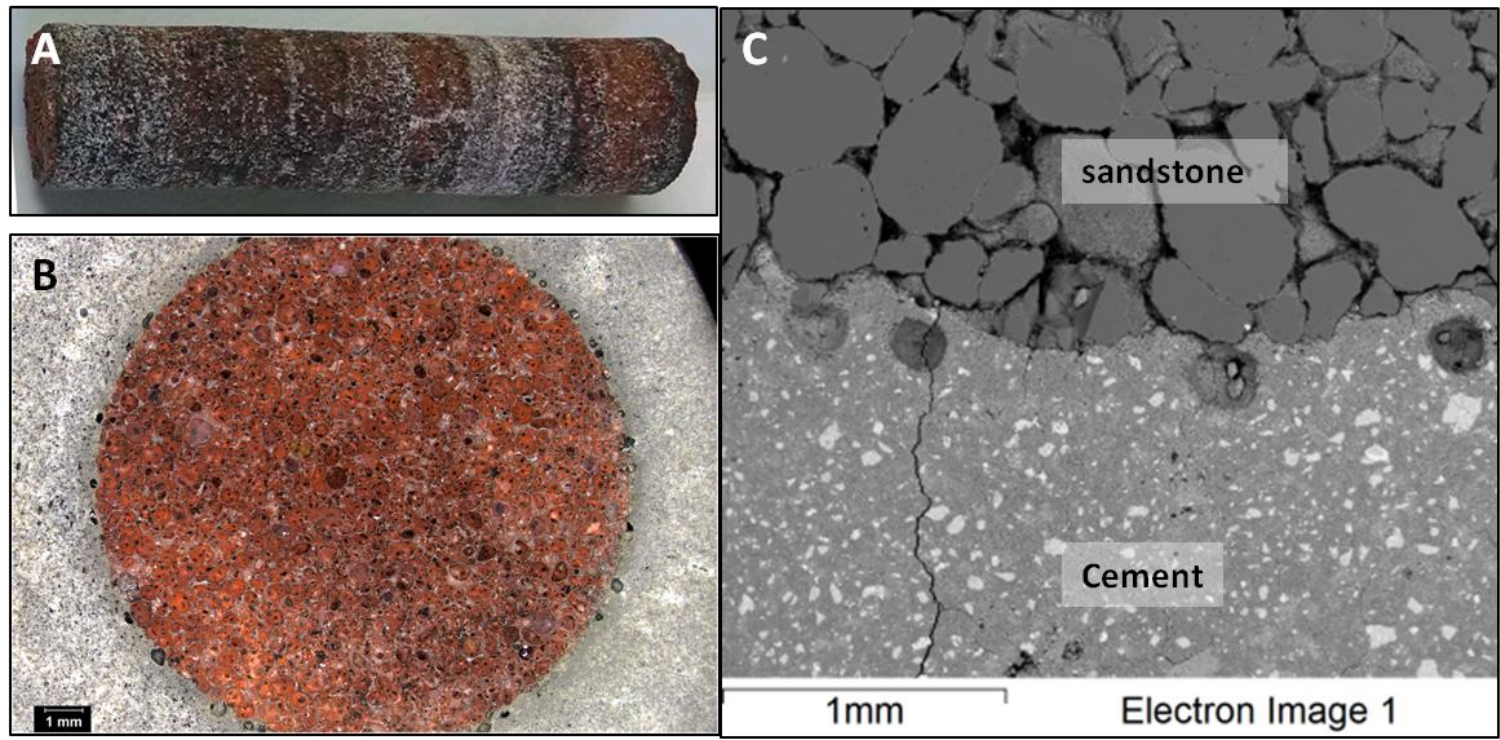

694 Figure 4: (A) 4" Mt. Simon sandstone sub-core. (B) Reflected photomicrograph of 695 oxidized rust red Mt. Simon sandstone encased in grey Lafarge Class $\mathbf{H}$ cement. (C) 696 SEM-BSE image of the cement-sandstone interface. 


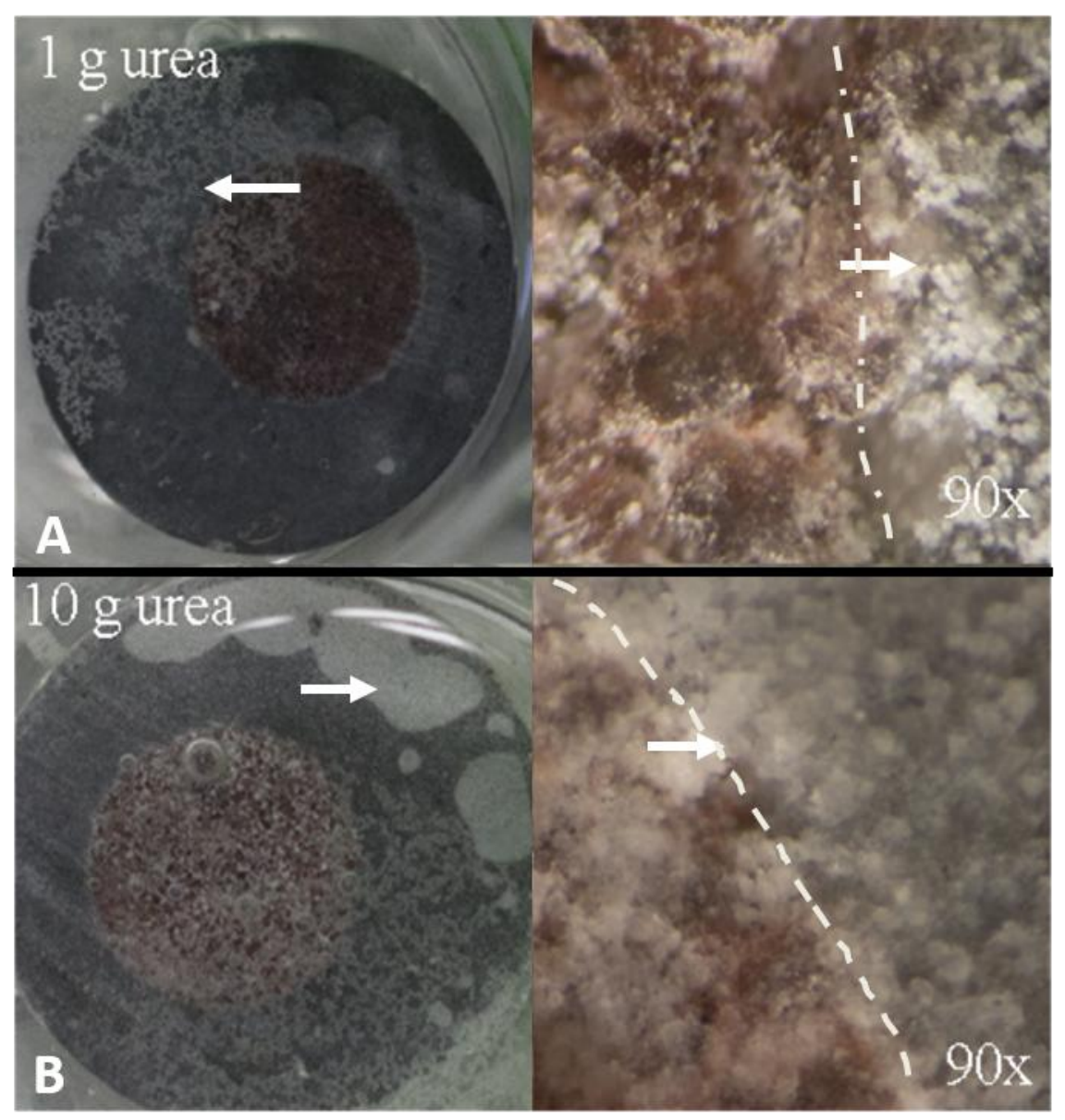

699 Figure 5: Growth of S. pasteurii on the cement-sandstone samples (interface dashed 700 line) immersed in (A) $1 \mathrm{~g} / \mathrm{L}$ or (B) $10 \mathrm{~g} / \mathrm{L}$ urea concentrations and subsequent 701 microbe colony growth (white arrow). Magnification increases from left to right with the maximum magnification $\sim 90 x$ on a Canon T3i mounted to a Leica M80 stereoscope. There is $\sim 17 \%$ biofilm surface area at $1 \mathrm{~g} / \mathrm{L}$ and $\sim 61 \%$ biofilm surface area at $10 \mathrm{~g} / \mathrm{L}$ with the majority of the biofilm attached to the cement as calculated using ImagePro. 

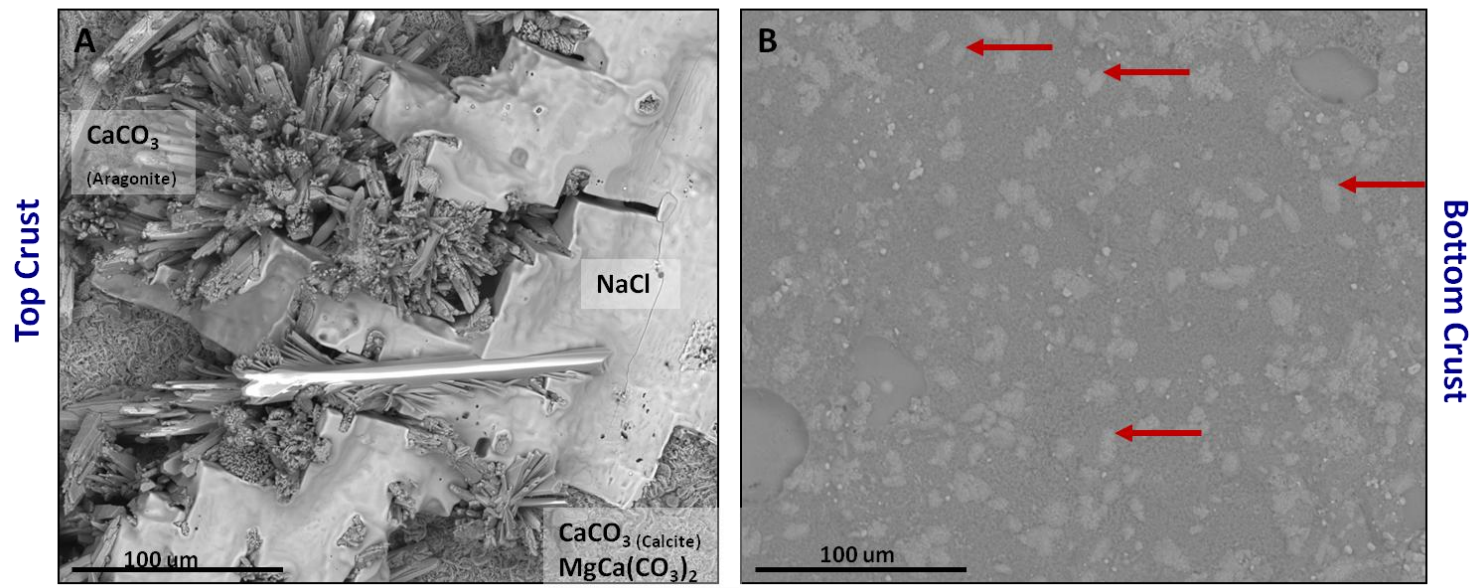

708 Figure 6: Effect of culture growth on cement-sandstone surfaces at atmospheric pressure in a brine augmented with $10 \mathrm{~g} / \mathrm{L}$ urea. (A) Several types of $\mathrm{CaCO}_{3}$, (acicular aragonite and calcite) and $\mathrm{MgCa}\left(\mathrm{CO}_{3}\right)_{2}$ (dolomite). These minerals are not seen under abiotic conditions. (B) Underside of the biogenic crust with calcified features consistent with microbial cells (6-7 $\mu \mathrm{m}$ in length and 3.1-3.3 wide) (red arrows). 


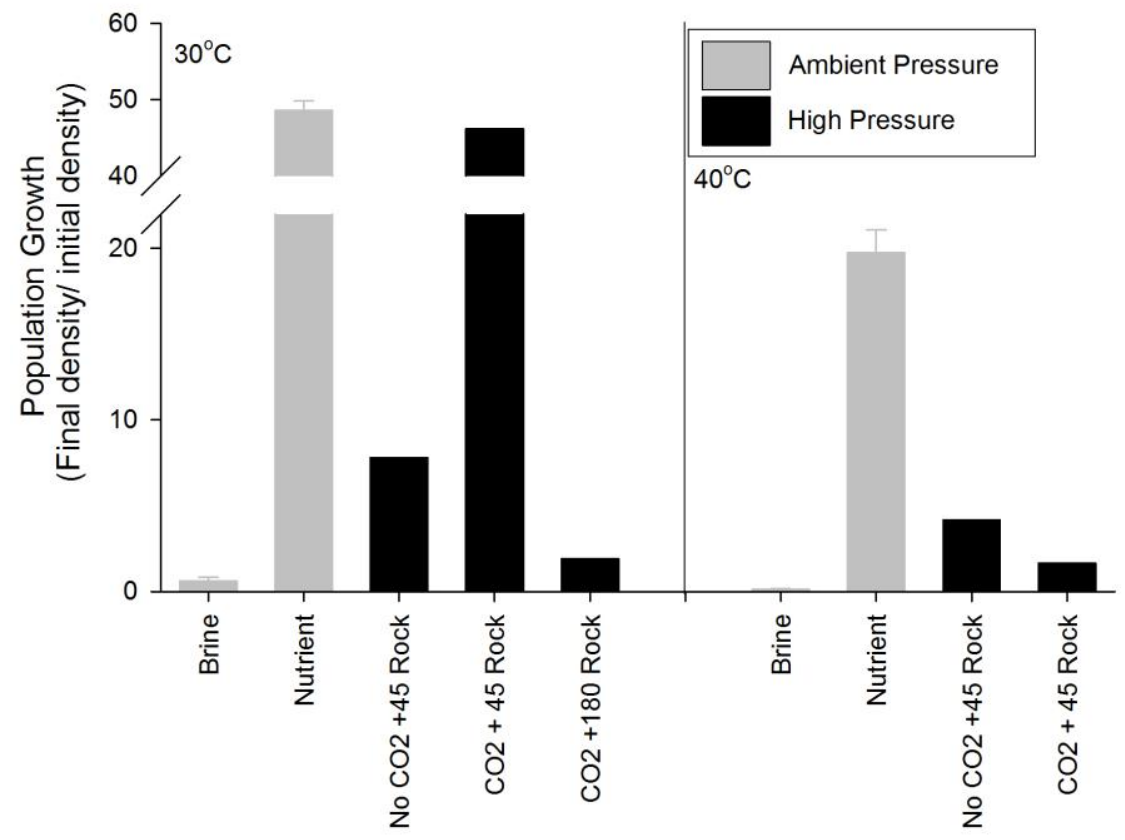

719 Figure 7: The change in population growth as indicated by the final/initial density of $S$. pasteurii over incubations at both ambient (grey) and high pressure experiments (black) of the lab experiments from Section 3. The addition of $\mathrm{CO}_{2}$ gas and degree of 

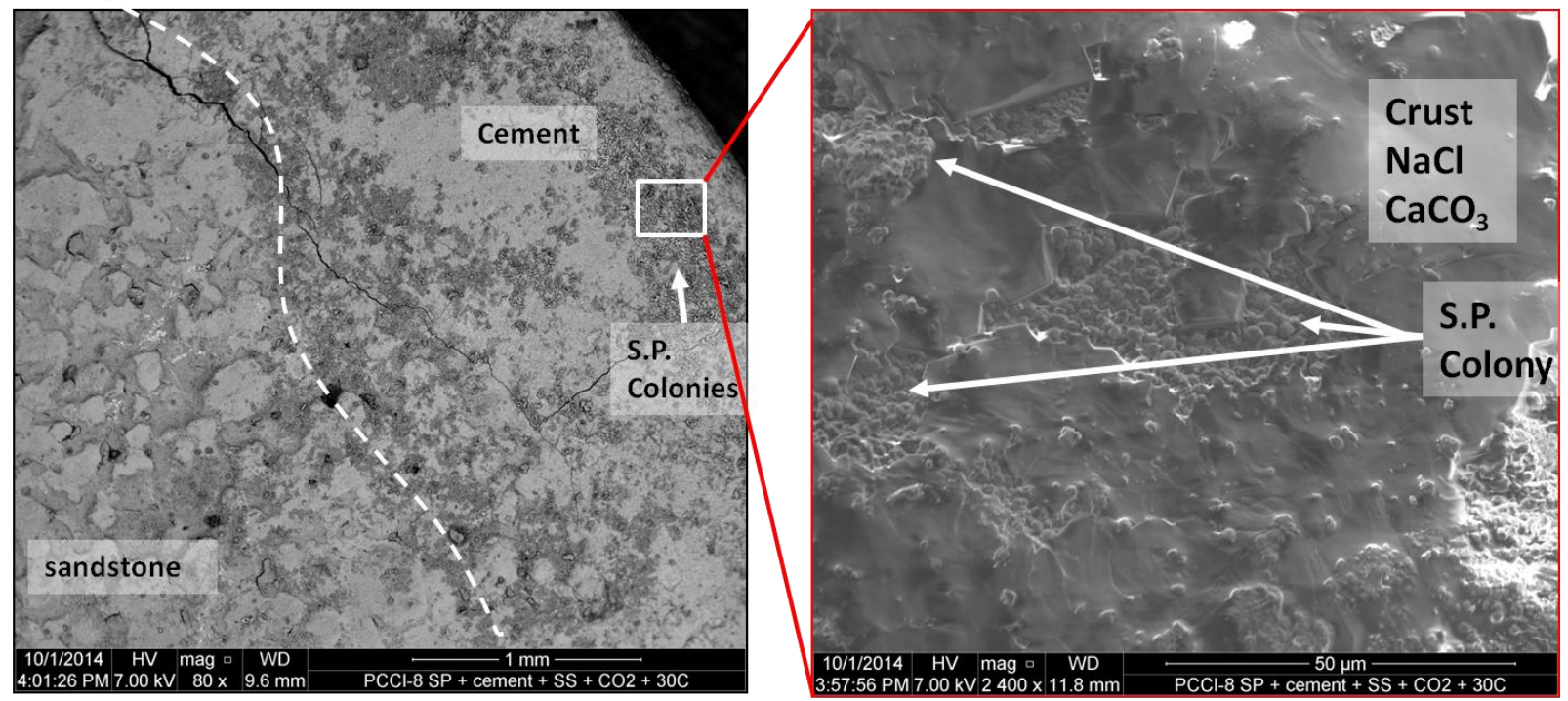

Figure 8: (A) SEM images of cement-sandstone surfaces following 2 week incubation in a rocking autoclave at $30{ }^{\circ} \mathrm{C}$ and $P_{\mathrm{CO}_{2}}=10 \mathrm{MPa}$. Dark patches at the right are a biofilm with calcium carbonate, indicative of growth and cementation by $S$. pasteurii, which is more prevalent on the cement substrate. (B) Enlargement of colonies that encase themselves within a $\mathrm{CaCO}_{3}$ crust. 

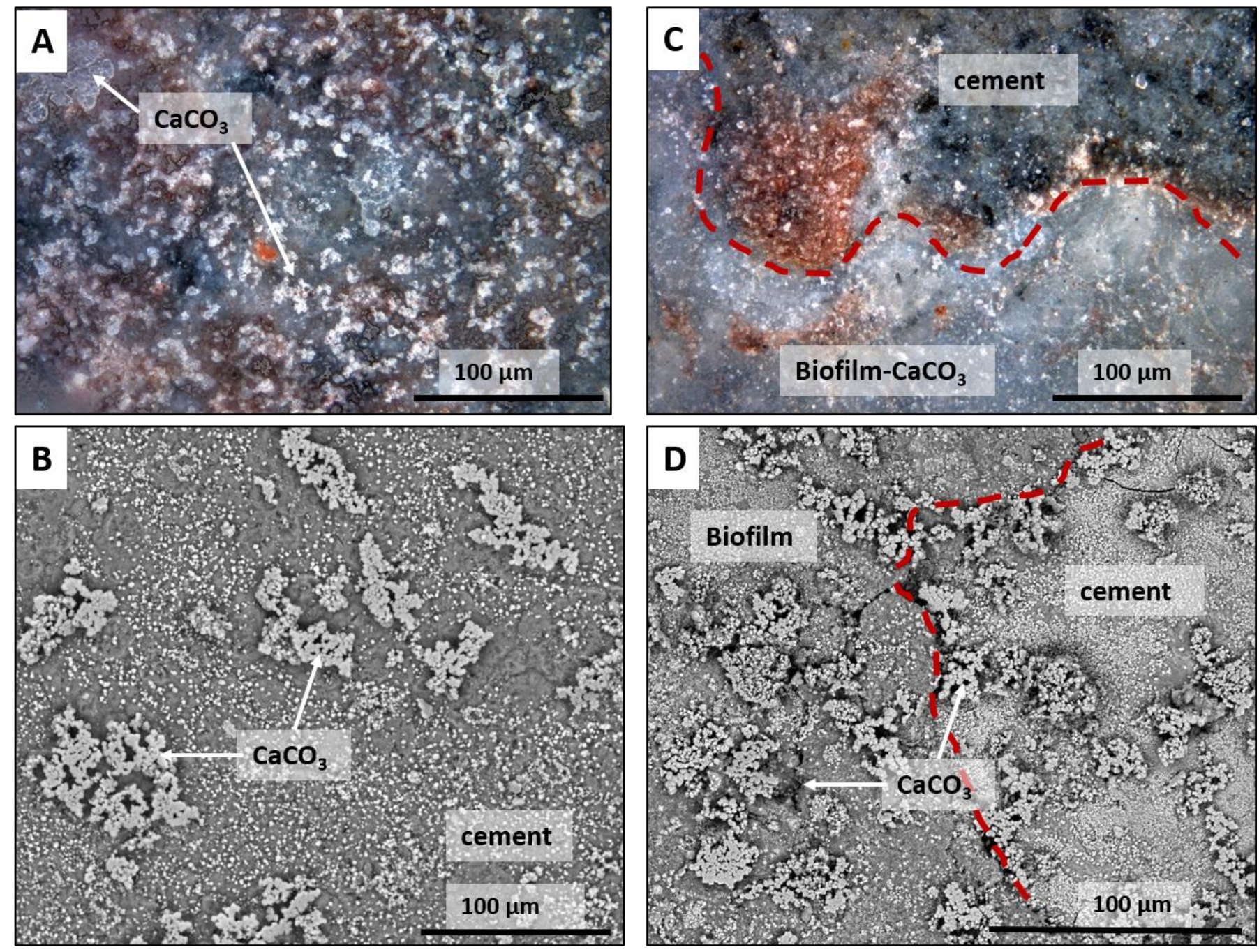

Figure 9: Reflected microphotographs and SEM-BSE comparison between

736 experiments conducted at $30^{\circ} \mathrm{C}$ under $\mathbf{P}_{\mathrm{CO} 2}=10 \mathrm{MPa}$ without $(\mathrm{A}, \mathrm{B})$ and with $(\mathrm{C}$,

737 D) microbial inoculation (dashed line shows biofilm boundary). SEM-BSE images

738 comparing (B) the presence of distributed $\mathrm{CaCO}_{3}$ in the abiotic specimen and (D)

739 distinct crystal structures when sample was incubated with $\mathbf{S}$. pasteurii. 

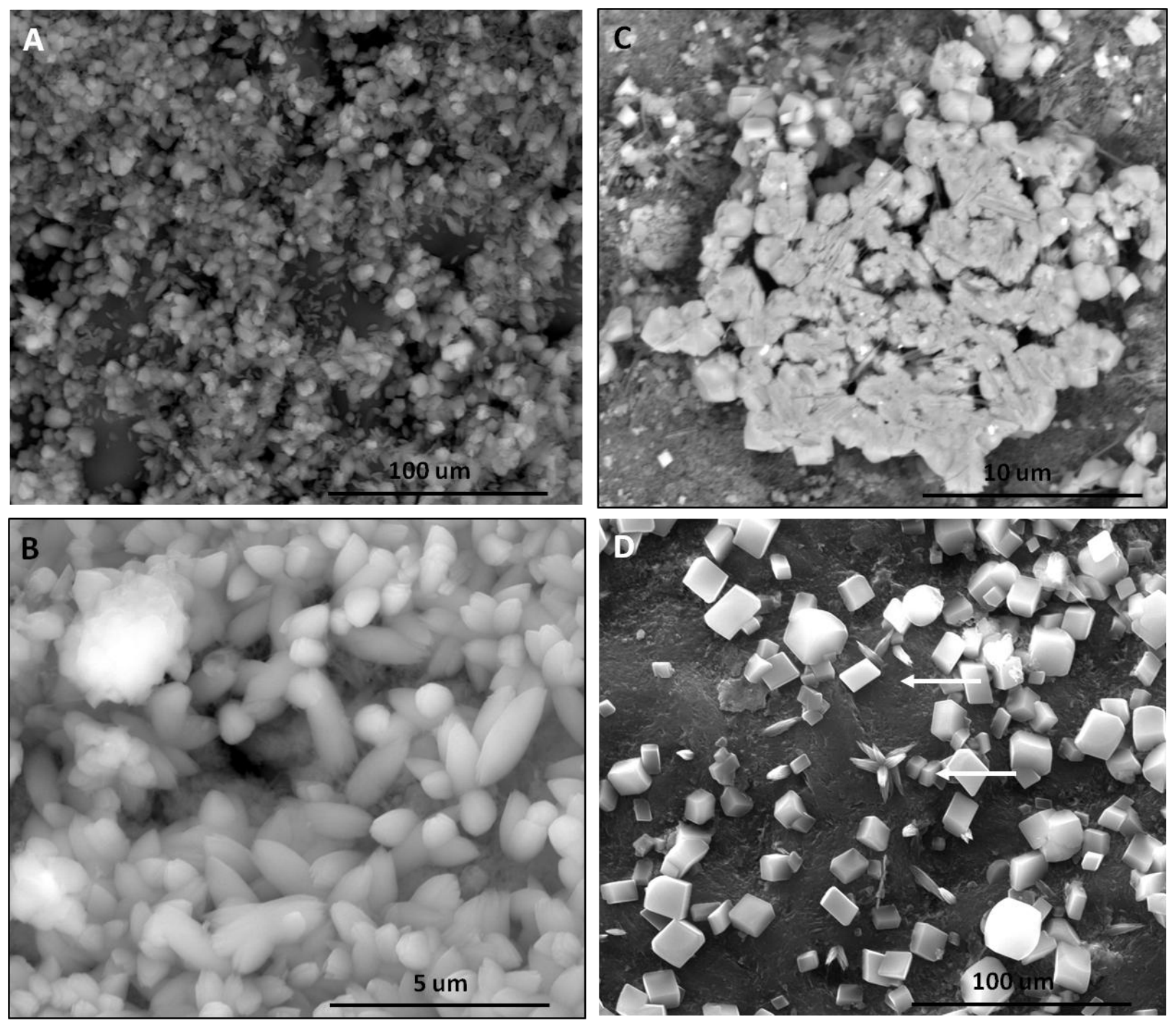

Figure 10: Additional SEM images showing the difference between abiotic (A, B) and biotic $(\mathrm{C}, \mathrm{D})$ incubations in the rocking autoclave at $30{ }^{\circ} \mathrm{C}$ and $10 \mathrm{MPa} \mathrm{P}_{\mathrm{CO} 2}$. (A) Overall view of secondary $\mathrm{CaCO}_{3}$ precipitation. (B) Close up view of secondary $\mathrm{CaCO}_{3}$ precipitation (A) Mineral replacement of $\mathrm{Ca}(\mathrm{OH})_{2}$ forming polycrystalline vaterite and calcite. (C) Clustered hexagonal $\mathrm{CaCO}_{3}$ (D) Rhombohedron calcite, orthorhombic aragonite, and acicular aragonite (arrows). 

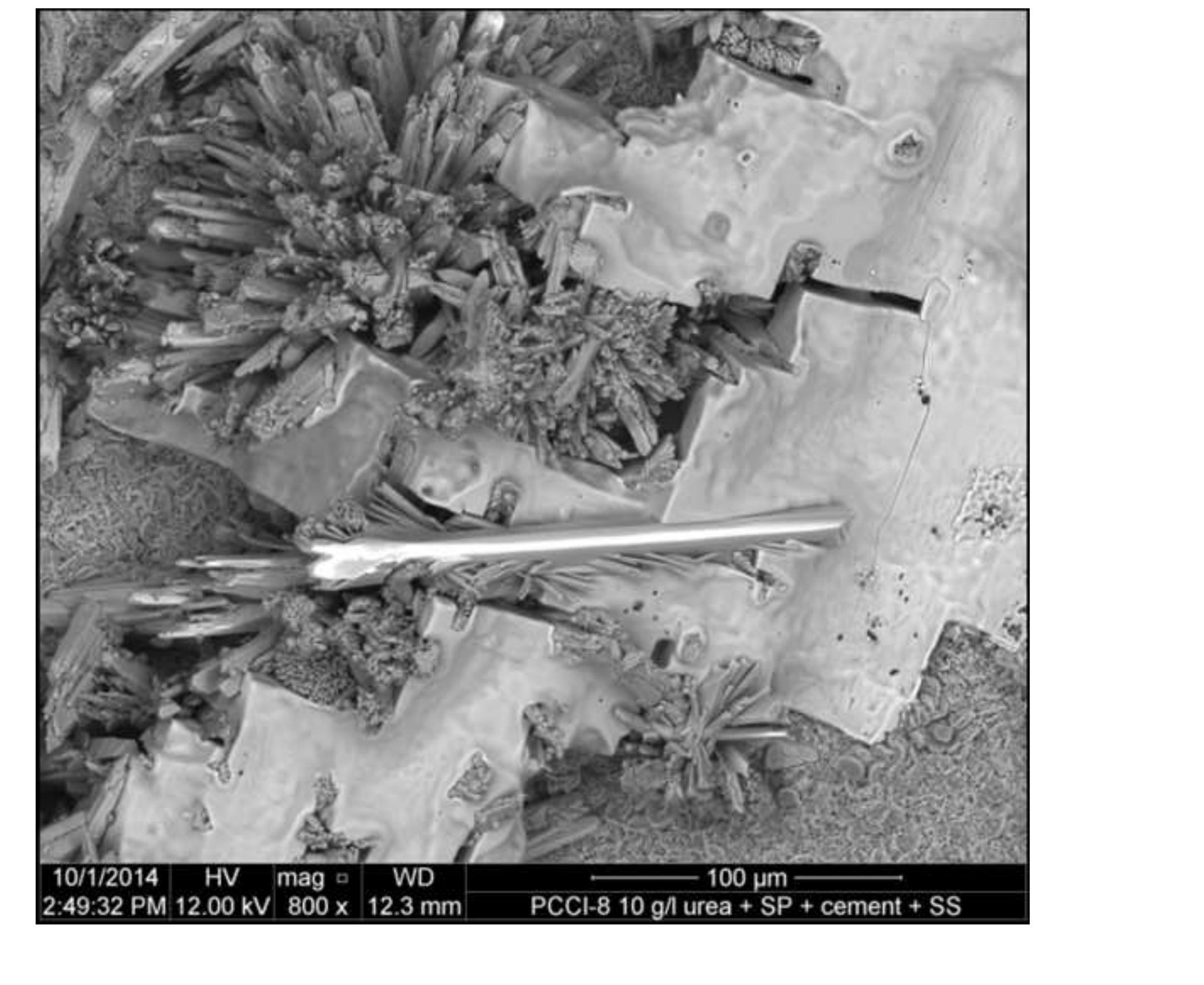